\title{
Current Account Imbalances in the
} Southern Euro Area

\author{
Florence Jaumotte and Piyaporn Sodsriwiboon
}


(C) 2010 International Monetary Fund

$\mathrm{WP} / 10 / 139$

\title{
IMF Working Paper
}

European Department

\section{Current Account Imbalances in the Southern Euro Area}

\section{Prepared by Florence Jaumotte and Piyaporn Sodsriwiboon ${ }^{1}$}

Authorized for distribution by James Daniel

June 2010

\begin{abstract}
This Working Paper should not be reported as representing the views of the IMF. The views expressed in this Working Paper are those of the author(s) and do not necessarily represent those of the IMF or IMF policy. Working Papers describe research in progress by the author(s) and are published to elicit comments and to further debate.

The paper examines the causes, consequences, and potential cures of the large current account deficits in the Southern Euro Area (SEA). These were mostly driven by a decline in private saving rates. But it was the European Monetary Union and the Euro, which enabled these countries to maintain investment rates, and thus run larger current account deficits, by improving their access to the international pool of saving. The paper finds that the deficits in SEA in 2008 were larger than can be explained by fundamentals, though the situation varies substantially across countries. It also finds that although the global financial crisis has started to force some unwinding, the current account deficits are expected to remain high in the medium run, though again with substantial variation across countries. The paper argues these large external deficits pose risks to the economy and therefore matter, even in a currency union, and discusses some policy options to reduce them.
\end{abstract}

JEL Classification Numbers:F21, F32, F36

Keywords: Current account, euro area, financial liberalization, financial integration Author's E-Mail Address: fjaumotte@imf.org; psodsriwiboon@imf.org

\footnotetext{
${ }^{1}$ The authors wish to thank James Daniel for his guidance in developing this project. We are grateful to the Exchange Rate Issues Division in the Research Department at the IMF for data and suggestions on CGER methodology. We are also thankful for helpful comments from Céline Allard, Michele Ca'Zorzi, Charis Christofides, Wouter Coussens, Stephan Danninger, Xavier Debrun, Luc Everaert, Yougesh Khatri, Peter Kunzel, Marialuz Moreno Badia, Hanan Morsy, Massimiliano Pisani, Antonio Spilimbergo, Bob Traa, Athanasios Vamvakidis, Claire Waysand, attendants at the European Department's seminar and at the conference "Italy's External Competitiveness" that took place in Rome on November 24-25, 2009.
} 
I. Introduction.

II. What Explains the Rise in Current Account Deficits in Southern Euro Area Countries?

III. Do the Current Account Deficits Exceed Norms?

IV. Policy Options in a Currency Union .................................................... 17

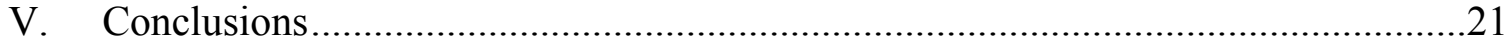

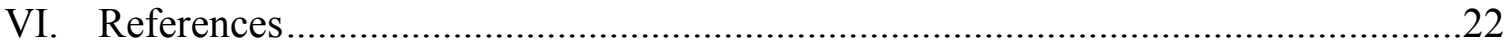

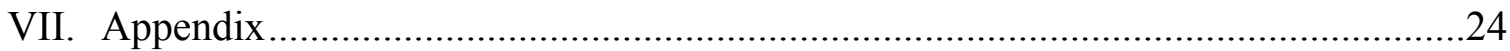

Tables

1. Contributions to Current Account Deficits of SEA in 1994 and 1998 .....................7

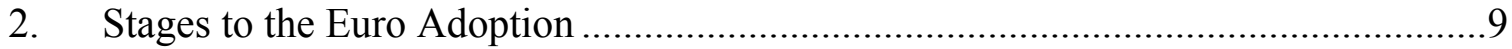

3. Determinants of the Current Accounts and Saving and Investment Rates ...............12

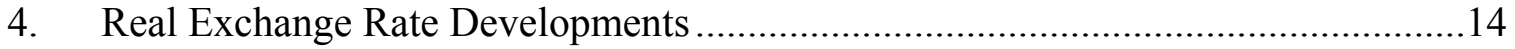

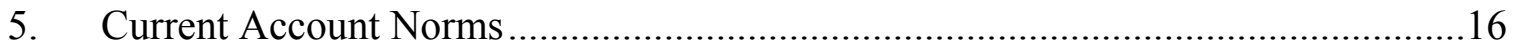

6. Contributions of Current Account Norms............................................................. 17

7. The Improvement in Current Accounts from Policy Changes..............................20

8. Determinants of the Current Account Balance ..................................................28

9. Robustness Tests of Current Account Regression .............................................29

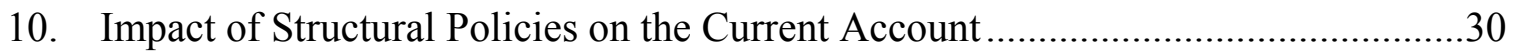


Figures

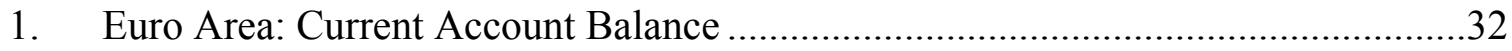

2. Southern Euro Area Countries: Current Account Balances 1970-2008...................33

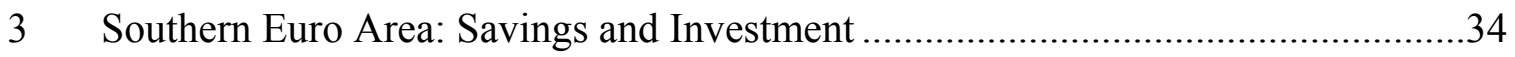

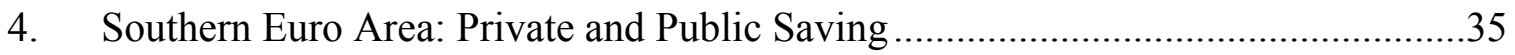

5. Southern Euro Area: Private and Public Investment ...........................................36

6. Southern Euro Area: Financing of Current Account Balances ............................37

7. Euro Area: Components of Current Account Balances ........................................38

8. Net International Investment Position ................................................. 38

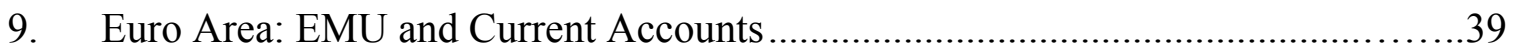

10. Southern Euro Area: EMU and Financial Liberalization .....................................40

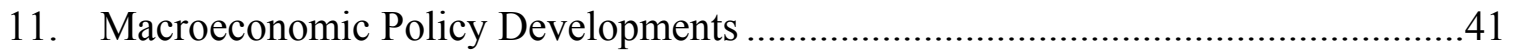

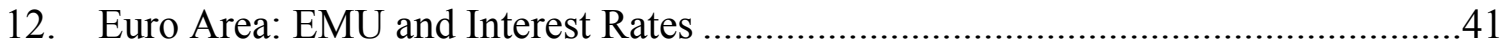

13. Euro Area: Contributions to Changes in Current Accounts, Savings and Investments Rates, 2005-2008 versus 1989-1992 .............................................................42

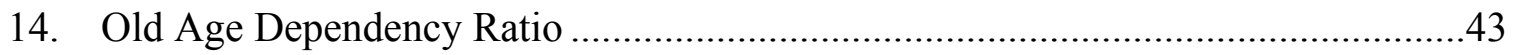

15. Southern Euro Area: Contributions to Difference in Current Accounts, Savings Rates and Investment Rates from Northern Euro Area, 2005-2008 ...............................44

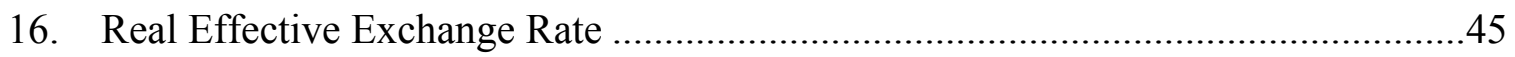

17. Euro Area: EMU, Economic Growth, and Output Gaps ....................................47

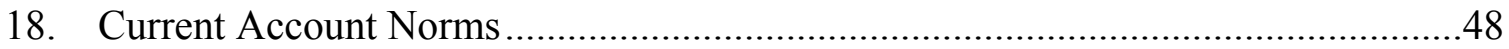

19. The Unwinding of Imbalances from the Global Crisis ......................................49 


\section{INTRODUCTION}

Since the mid-1990s, Southern Euro Area² (SEA) countries have seen their current accounts deteriorate sharply, from balance to large deficits of about 10 percent of GDP. In contrast, Northern Euro $\mathrm{Area}^{3}$ (NEA) countries accumulated surpluses. These facts raise three sets of questions on which this paper attempts to shed light: (1) what caused the large current account deficits in SEA, and are they connected to the formation of the European Monetary Union (EMU) and subsequently the euro? (2) do they exceed "norms" (equilibrium levels as determined by fundamentals)? (3) do they matter in a currency union and, if so, what are the policy choices to help reduce the imbalances in the absence of the exchange rate instrument?

- $\quad$ The paper finds that the decline in the current accounts coincided with a large decrease in private saving rates and a much more moderate increase in investment rates. The declines in private saving were spurred by the financial liberalization that took place in the early and mid-1990s, and increasing dependency ratios. The creation of EMU and, especially, the introduction of the euro, contributed to the declines in current accounts by allowing countries to maintain their investment levels above what could be financed from domestic saving. Economic integration improved access to the international pool of saving, although it did not necessarily make it optimal or sustainable. There is evidence for a number of countries that investment took place in less productive nontradable sectors, such as construction. And while the public sector did increase its savings somewhat, it was less than in the NEA and not enough to offset the sharply lower private savings.

- The paper finds evidence that indicates that the 2008 current account deficits of most SEA countries exceed norms, though with substantial variation across countries. The current global financial crisis is forcing some reduction in current account deficits and deleveraging of balance sheets, as domestic demand and imports contract, again, with substantial variation across countries. Nevertheless, current account deficits are expected to remain high in the medium-run, as a result of the countries' low productivity and weak competitiveness.

- $\quad$ The paper argues that the large current account deficits threaten the economy and therefore matter, even in a currency union, and explores a menu of policy options including: (1) fiscal consolidation to increase government saving; (2) an "internal devaluation" to mimic a real devaluation through lowering unit labor costs; (3) structural policies to increase productivity and growth, including in the nontradable sector; and (4) tightening financial policies to curb credit growth and improve loan

\footnotetext{
${ }^{2}$ The Southern Euro Area comprises Cyprus, Greece, Italy, Malta, Portugal, Slovenia, and Spain.

${ }^{3}$ The Northern Euro Area consists of Austria, Belgium, Finland, France, Germany, Ireland, Luxembourg, and the Netherlands.
} 
quality. As an illustration, the paper finds that labor productivity and minimum wages have a large effect on current account balances.

This paper is organized as follows. The next section analyzes some stylized facts to explain what is behind SEA's current account deficits. It then uses regression analysis, based on the $\mathrm{CGER}^{4}$ setting, to identify the determinants of current accounts and how much they contributed to the large decline in current account balances in SEA. The following section discusses whether the current account deficits are excessive and unsustainable, including by calculating equilibrium current accounts using CGER-type methodologies. The next section argues why large current account deficits matter, even in a currency union, and presents some policy options to reduce them. The last section concludes.

\section{WHAT EXPLAINS THE RISE IN CURRENT ACCOUNT DEFICITS IN SOUTHERN EURO AREA COUNTRIES?}

\section{Stylized facts}

Current accounts in the SEA have been deteriorating sharply since the mid-1990s, growing from a surplus of 0.1 percent on average in 1994 to a deficit of 10 percent in 2008 (Figures 1 and 2). ${ }^{5}$ This downward trend is shared by most countries in the region, although it started later for Cyprus, Malta, and Slovenia than for Greece, Italy, Portugal and Spain coinciding with their later entry into the EMU and euro area. This overall pattern of growing external deficits is in sharp contrast to NEA which accumulated current account surpluses of the order of 2-3 percent of GDP after $1994 .^{6}$

While the paper simplifies for the sake of the analysis, it should be noted that the north-south divide is not clear-cut and there is also variation within groups. On the one hand, current account deficits remained at more moderate levels in Malta, Slovenia, and especially Italy (3 percent of GDP). On the other hand, some NEA countries (e.g. Ireland) were also running large current account deficits prior to the crisis. Countries within a group also have different structural settings (e.g. financial sector size and development, labor market institutions) and starting positions (e.g. savings, competitiveness and per capita income).

The decline in current accounts in SEA was accompanied by a fall in private saving and to a lesser extent a rise in investment (Figures 3 and 4). On average across the region, private saving rates declined by 10 percentage points between 1994 and 2008, while investment rates increased by 2 percentage points and public saving rates improved by about 2 percentage points. Of course, the distribution between saving and investment varies across countries. In

\footnotetext{
${ }^{4}$ Consultative Group on Exchange Rate Issues (CGER), see Lee et al. (2008).

${ }^{5}$ All averages are unweighted, unless otherwise indicated.

${ }^{6}$ The dating of this turnaround for the Northern group of countries coincides with the emergence of sustained wage moderation in Germany after the unification cost blowout in 199-94.
} 
Greece, Italy, Portugal, Cyprus and Malta, declines in private saving rates were the predominant factor behind the decline in the current account. Spain is a well-known example where investment boomed, especially in the construction sector, but falling private saving rates contributed equally to the deterioration of its external position. In Slovenia investment boomed too, while private saving actually improved. Cyprus and Malta experienced an investment boom after EU accession in 2004. However, investment still remained below the high levels of the mid-1990s. In countries where it increased, investment went mostly to the construction sector, while investment in machinery and equipment only increased moderately or declined, suggesting that much of the rise in investment permitted by higher external debt was channeled into the less productive nontradeable sectors (Figure 5).

While saving and investment rates started broadly similar to those of NEA in 1994, they have been diverging substantially in subsequent years. By 2008, saving rates in most SEA countries were substantially below the average for NEA, due to both lower private and public saving, while investment rates were broadly in line with the average level in NEA except in Spain and Slovenia, where they were much higher. It is interesting to note that while public saving improved over the period in SEA, it did less so than in NEA. Hence, the relative buoyancy of the private sector in SEA was compounded by a less restrictive stance of the public sector than in NEA.

The current account deficits were heavily financed with debt instead of FDI (Figure 6). The larger countries, Spain, Greece and to a lesser extent Italy, were large importers of bond-related inflows, while Portugal and Slovenia took in large foreign loans. ${ }^{7}$ Cyprus and Malta are a bit of an exception, in that they received substantial net FDI inflows of the order of 5 and 10 percent of GDP respectively on average over the period 2000-2008 ${ }^{8}$. Cyprus also relied on non-resident deposits to finance its current account deficit, while Malta used very large inflows of non-resident deposits to invest in non-resident assets with a neutral effect on its financial account.

The decline in saving and increase in investment had their counterparts in a fall of the trade balance (as imports increased), a large decrease in net income, and a decline in net transfers (Figure 7, Table 1). Of the 10 percentage point average decline in the current account, the trade balance contributed 2.8 percentage points, net income contributed 3.6 percentage points, and net transfers 3.6 percentage points. Excluding oil, the trade balance improves slightly, but the deterioration of the current account remains sizeable at some $6 \frac{1}{2}$ percentage points on average. Excluding net interest payments, which reflect past current accounts, the deterioration in the primary current account balance is still $71 / 2$ percentage points.

\footnotetext{
${ }^{7}$ For Portugal, some of the financing that appears as foreign loans is the counterpart of the issuance of bonds abroad. Portuguese banks have issued bonds through foreign affiliates, which then channel financial resources to the domestic institution.

${ }^{8}$ Given their small scale, Cyprus and Malta benefited especially from the expansion in advanced economies, which accelerated the demand for vacation homes and created significant FDI inflows for housing into Cyprus and Malta. EU accession and later euro adoption also enabled these countries, especially Malta, to attract productive foreign investment in call centers, aircraft maintenance and financial services.
} 
SEA countries differ largely in their net foreign asset positions, with different implications for their current account dynamics. Greece, Portugal and Spain have among the worst net foreign asset positions among all advanced countries (Figure 8). These are exerting strong negative debt dynamics through rapidly declining net portfolio and other investment income. ${ }^{9}$ In contrast, Cyprus, Malta, Slovenia and Italy have positive or only slightly negative net foreign asset positions. ${ }^{10}$

Table 1. Contributions to Current Account Deficits of SEA in 1994 and 2008 (Percent of GDP)

\begin{tabular}{|c|c|c|c|c|c|c|c|c|c|c|}
\hline & \multicolumn{2}{|c|}{ SEA } & \multicolumn{8}{|c|}{ Differences between 1994 and 2008} \\
\hline & 1994 & 2008 & SEA & Cyprus & Greece & Italy & Malta & Portuga & Sloveni & Spain \\
\hline Current Account Balance & 0.1 & -9.9 & -10.0 & -18.7 & -14.4 & -4.7 & -3.4 & -9.8 & -10.4 & $\begin{array}{c}-8.4 \\
\end{array}$ \\
\hline Trade Balance & -3.5 & -6.3 & -2.8 & -12.4 & -5.9 & -4.1 & 15.3 & -1.5 & -5.4 & -5.7 \\
\hline Trade balance excl. oil balance & -1.2 & -0.7 & 0.6 & -9.4 & -2.1 & -2.8 & 21.3 & 3.0 & -3.2 & -2.9 \\
\hline Net Income & -0.1 & -3.7 & -3.6 & -4.5 & -3.3 & -0.3 & -7.5 & -4.1 & -3.8 & -1.6 \\
\hline Of which: from FDI & 0.1 & -3.3 & -3.4 & -11.2 & -0.3 & 0.1 & -11.8 & -0.7 & -1.3 & 1.3 \\
\hline from portfolio and other investment & -0.6 & -0.7 & -0.1 & 3.8 & -3.3 & -0.4 & 7.1 & -3.3 & -1.5 & -2.9 \\
\hline Net Transfer & 3.6 & 0.1 & -3.6 & -1.7 & -5.2 & -0.3 & -11.2 & -4.2 & -1.1 & -1.1 \\
\hline Current Account Balance excl. Oil Balance 1 & / 2.3 & -4.2 & -6.6 & -16.3 & -10.4 & -3.4 & 2.7 & -5.4 & -7.6 & -5.5 \\
\hline Primary Current Account Balance 2/ & -3.9 & -11.4 & -7.5 & -16.4 & n.a. & n.a. & -14.4 & -7.7 & -4.9 & -6.3 \\
\hline
\end{tabular}

Source: IFS statistics

1/ Current account balance excluding oil balance

2/ Primary current account balance is current account balance net of interest payments.

\section{The role of $E M U$}

The decline in SEA current accounts coincided with the creation of the European Monetary Union (EMU) and its subsequent introduction of the euro. After a first stage of financial liberalization that occurred broadly between 1990 and 1993, the four largest SEA countries (Greece, Italy, Portugal, and Spain) joined EMU in 1994 and the euro area in 1999 (2001 for Greece). The three smaller SEA countries (Cyprus, Malta, and Slovenia) started the process later, by joining the EMU around 2004 and the euro area in 2007-2008 (Table 2). These dates correspond broadly to the start of the deterioration of current accounts (EMU) and its subsequent acceleration (euro area) (Figure 9). Hence, it is natural to ask whether participation into EMU caused this decline and if so, through which mechanisms. ${ }^{11}$ In what follows, the four early joiners are referred to as SEA-4 and the three later joiners as SEA-3.

\footnotetext{
${ }^{9}$ In the Spanish case, foreign savings have also financed a strong process of investment abroad by Spanish companies in dynamic areas of the world. Some of these investments could mature in due time and translate into improved income balances.

${ }^{10}$ The strong decline in net investment income in Cyprus and Malta reflects a specific accounting practice. Income from FDI that is reinvested in the country is both recorded as an outflow of investment income (in the current account) and an inflow of capital (in the financial account).

${ }^{11}$ The creation of the EMU proceeded in three stages. The first consisted of financial liberalization aimed at completing the single market and occurred broadly between 1990 and 1993. The second stage was marked by economic policy convergence and reduced exchange rate volatility (through the Exchange Rate Mechanism) in preparation for the introduction of a common currency. It spanned 1994-1998 for most euro countries. The final stage was the introduction of the euro which took place in 1999.
} 
SEA countries made great strides in financial liberalization, converging towards levels in NEA countries (Figure 10). ${ }^{12}$ Liberalization was broad-based, involving relaxation of capital controls, entry barriers, quantitative credit controls, and improved financial supervision, although privatization efforts were slower. While substantial financial liberalization took place in the earlier stage of EMU, it has also been driven by exogenous non-EU related developments and by the EU internal market project. However, the "gates" were open to let capital and credit flow in once the European integration process intensified. Financial liberalization removed barriers to capital inflows, which triggered inflows into lower-income countries with bigger investment needs. The liberalization of domestic financial systems also reduced the need for domestic saving, as credit became more readily available. A narrower indicator focusing on capital account openness shows a similar picture for SEA-3 as for SEA-4, with financial liberalization largely taking place in the early stage of EMU. ${ }^{13}$

The creation of EMU was marked by a substantial improvement in macroeconomic policies in an effort to reach the "convergence criteria" ${ }^{14}$ to enter the euro area (Figure 11). In the early 1990s, SEA countries continued to run large fiscal deficits. During stage 2 of EMU, fiscal deficits of SEA were brought down at or below the 3 percent of GDP benchmark, except in Greece where they consistently stayed higher. Moreover, inflation in SEA declined from double-digit figures on average in the early 1990s to a low of 2 percent in 2007. The inflation differentials between SEA and NEA narrowed from 5.5 percent in 1994 to less than 1 percent in 2008. The potential effects on current accounts are twofold: on one hand, lower fiscal deficits and inflation help improve the current account; on the other, the sounder macroeconomic policies contributed to reducing interest costs on foreign borrowing, due to a lower country risk premium.

\footnotetext{
${ }^{12}$ The financial liberalization index is from Abiad et al. (2008) and combines information on interest rate controls, credit controls, competition restrictions, state ownership, quality of the banking supervision and regulation, and policies to permit access by foreigners to the domestic stock market.

${ }^{13}$ The indicator of capital account openness is from Chinn and Ito (2006).

${ }^{14}$ The convergence criteria include (i) the government deficits must not exceed 3 percent of GDP and the public debt must not exceed 60 percent of GDP; (ii) the inflation rate is within \pm 1.5 percent of the average of the three lowest inflation rates among Member States; (iii) a long-term nominal interest rate does not exceed by 2 percentage points the average of the three best performing Member States on inflation; (iv) a currency must not have been devalued on its own initiative in the previous two years and must have remained within the normal fluctuation margins of the ERM.
} 
Table 2. Stages to the Euro Adoption

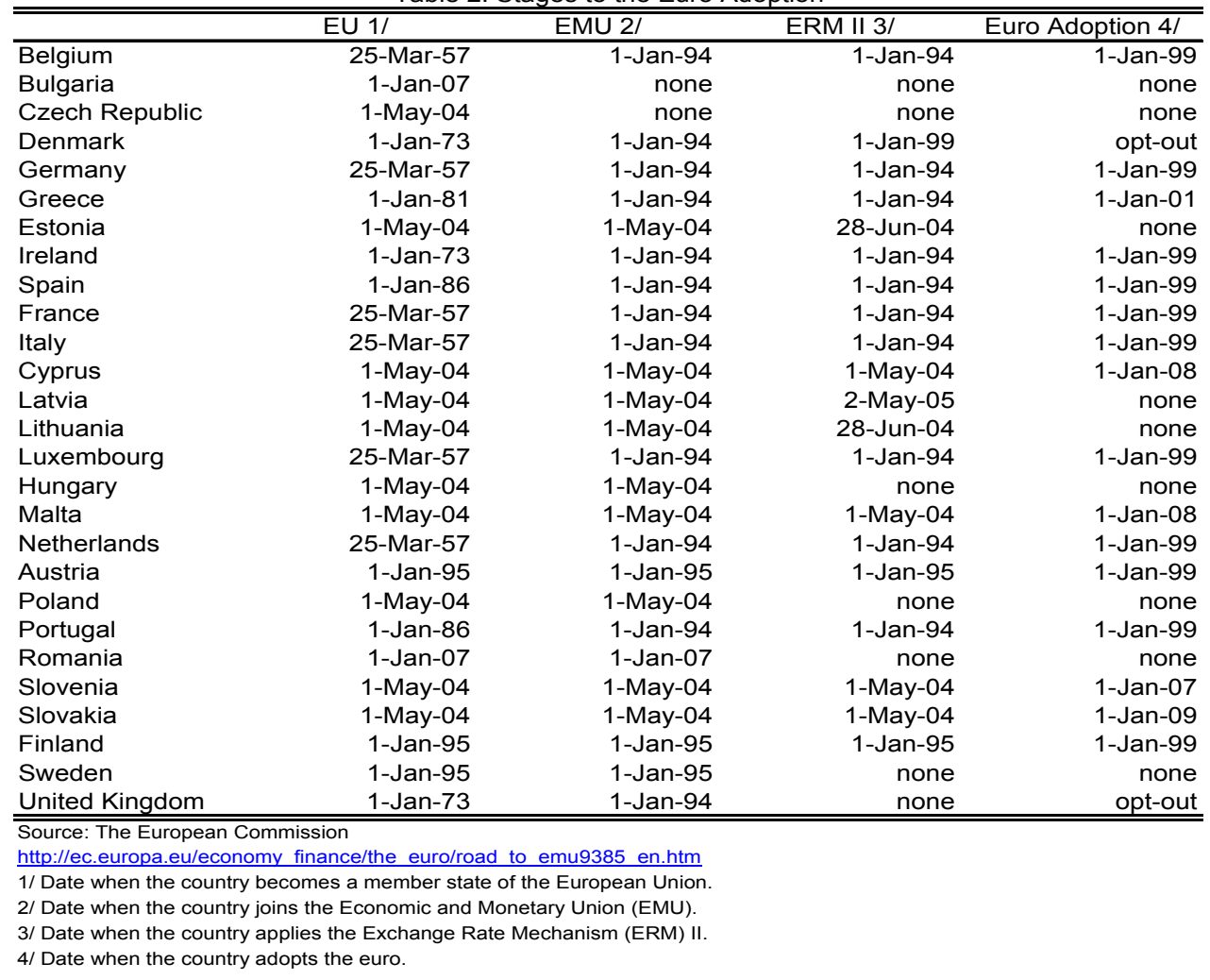

Reflecting improvement in macroeconomic policies and reduced exchange rate risk, SEA nominal and real interest rates fell rapidly and converged to the low levels in NEA countries (Figure 12). The bulk of interest rate declines occurred during stage two of EMU, as nominal interest rates on 10-year government bonds declined by 8 percentage points in SEA-4, and the interest rate differential with NEA fell from by 5.5 percentage points to about zero. Real interest rates declined by 5-6 percentage points and fell below those in NEA countries between 2000-2008. Short-term interest rates, also available for SEA-3, showed a similar picture in later years when they joined EMU.

\section{A quantitative analysis}

So how big was the effect of financial liberalization, EMU, and the adoption of the euro on SEA current accounts? To answer this, we use as a basis standard current account regressions, which control for a broad set of determinants of current account balances. ${ }^{15}$ The new effects are then tested by introducing measures of financial liberalization and dummy variables for participation in EMU and adoption of the euro. The EMU and euro adoption could have very different effects on the SEA and NEA, due to their different starting income

\footnotetext{
${ }^{15}$ For examples of standard current account regressions, see Calderón et al. (2000), Chinn and Ito (2006), Chinn and Prasad (2003), Gruber and Kamin (2007, 2008), and Lee et al. (2008). Ca' Zorzi et al (2009) examine model and parameter uncertainty for structural current account regressions. They find support for most of the variables that are typically included in current account regressions, although model uncertainty is higher for some variables.
} 
levels and/or different accompanying policies. Hence, both the EMU and euro adoption variables are allowed to have different impacts on Northern and Southern countries. ${ }^{16}$ The use of dummy variables avoids endogeneity problems that would affect interest and inflation rates, and is more encompassing should other effects have been omitted. ${ }^{17}$ The model is also estimated replacing the current account by the saving and investment rates, respectively, in order to shed more light on the channels through which financial liberalization, EMU, and euro adoption could have affected the current account.

While the results presented below appear reasonable, a few caveats should be acknowledged from the outset. First, it should be recognized that the use of differentiated dummies for northern and southern euro area addresses only partially the potential lack of homogeneity within the euro area. Estimated effects are average effects. Second, it may be difficult to disentangle effects from EMU from those of the adoption of the euro. Finally, the euro has been functioning for just over 10 years, a period of time that may not be long enough to be representative and makes difficult differentiating between cyclical and structural factors. The crisis in a number of European countries in 1992-93, followed by devaluations, is also an important factor that makes any comparison between 1994-98 and 1999 onwards challenging.

The analysis focuses on medium-run determinants (data are averaged over four-year periods) and covers a panel of 49 advanced and emerging economies during 1973-2008. ${ }^{18}$ Details of the econometric analysis are available in the Appendix and Table 3 summarizes the preferred specification. Standard determinants of the current account balances have the expected effects: the current account balance weakens with higher fiscal deficits, catching-up growth, increasing current dependency ratios, expected decreasing future dependency ratios, and lower net foreign assets. ${ }^{19}$ Turning to the impact of EMU-related variables, three results stand

\footnotetext{
${ }^{16}$ The EMU dummy variable takes value one for the years where the country belongs to EMU (starting from the more formal second stage) and zero otherwise. The euro dummy variable takes value one for the years where the country uses the euro and zero otherwise. The EMU-North dummy variable takes value one during EMU years for "Northern" countries, EMU-South takes value one during EMU years for "Southern" countries, and similarly for the euro dummy variables. A more complete way to test for the heterogeneity of the EMU and euro effects would be to allow the coefficients on all regressors (including the initial relative income per capita) to have a differentiated effect for EMU and euro observations. However, this is not feasible due to the relatively small number of EMU and euro observations and the large number of regressors.

${ }^{17}$ Introducing the real interest rate in the model yields a small and insignificant coefficient, even if it is instrumented. The endogeneity of interest rates is difficult to eliminate fully and tends to bias the coefficient downward. Yet, there is some evidence of a larger effect of interest rates when it is interacted with the dummy variable for participation into the EMU, perhaps because it is capturing a more exogenous change in interest rates. However, a proper test would require interacting all regressors with the EMU and euro dummies to test which coefficients are significantly different. As explained in Footnote 21, this is not feasible due to the small number of EMU and euro observations.

${ }^{18}$ The panel is unbalanced as the variables were not always available for all subperiods for all countries.

${ }^{19}$ The fiscal balance, GDP per capita growth, population growth, and dependency ratios are expressed in deviation from a weighted average of the variable in trade partners. While growth of income per capita is
} 
out: (i) financial liberalization weakened the current account balance, mostly by depressing saving rates; ${ }^{20}$ (ii) the impact of EMU on current accounts was positive for NEA, and negative but insignificant for SEA; and (iii) in contrast to EMU, euro adoption lowered current accounts substantially in both subregions by raising investment. How can these effects be explained?

While the diverging EMU effects may appear surprising at first, it needs to be recalled that EMU had offsetting effects on the current account: the improvements in macroeconomic policies induced by the convergence criteria may have led to improving current accounts in some countries but declining current accounts in other countries where it was accompanied by a sharp decline in interest rates. The balance of these effects may have been different in SEA and NEA. In addition, the creation of EMU opened the door to a surge in capital flows from NEA to SEA where investment needs were larger due to their lower initial income per capita, with opposite effects on the current accounts of both regions. In turn, euro adoption depressed current accounts in both SEA and NEA as it led to higher investment in both regions. A number of factors may have been at play, including a perception of higher growth prospects in the euro area as a whole due to its integration, and perhaps due to portfolio diversification into the euro on the part of international investors, which strengthened the new currency.

insignificant, the indicator of growth catching-up opportunities - the level of income per capita scaled by the US level - is significant.

${ }^{20}$ Danninger and Jaumotte (2008), using the same measure as in this paper, also find a negative effect of financial liberalization on the current account for a broad sample of advanced and emerging countries. Blanchard and Giavazzi (2002) find evidence suggesting that stronger economic integration leads to weaker current account balances for poorer countries, through falling saving rates. They also provide evidence suggesting that domestic financial liberalization leads to weaker current account balances. Abiad et al. (2007) show for a sample of European countries that financial integration leads countries to borrow more from abroad if they are relatively poor, and lend more to abroad if they are relatively rich. 
Table 3. Determinants of the Current Accounts and Saving and Investment Rates 1/ (Percent of GDP)

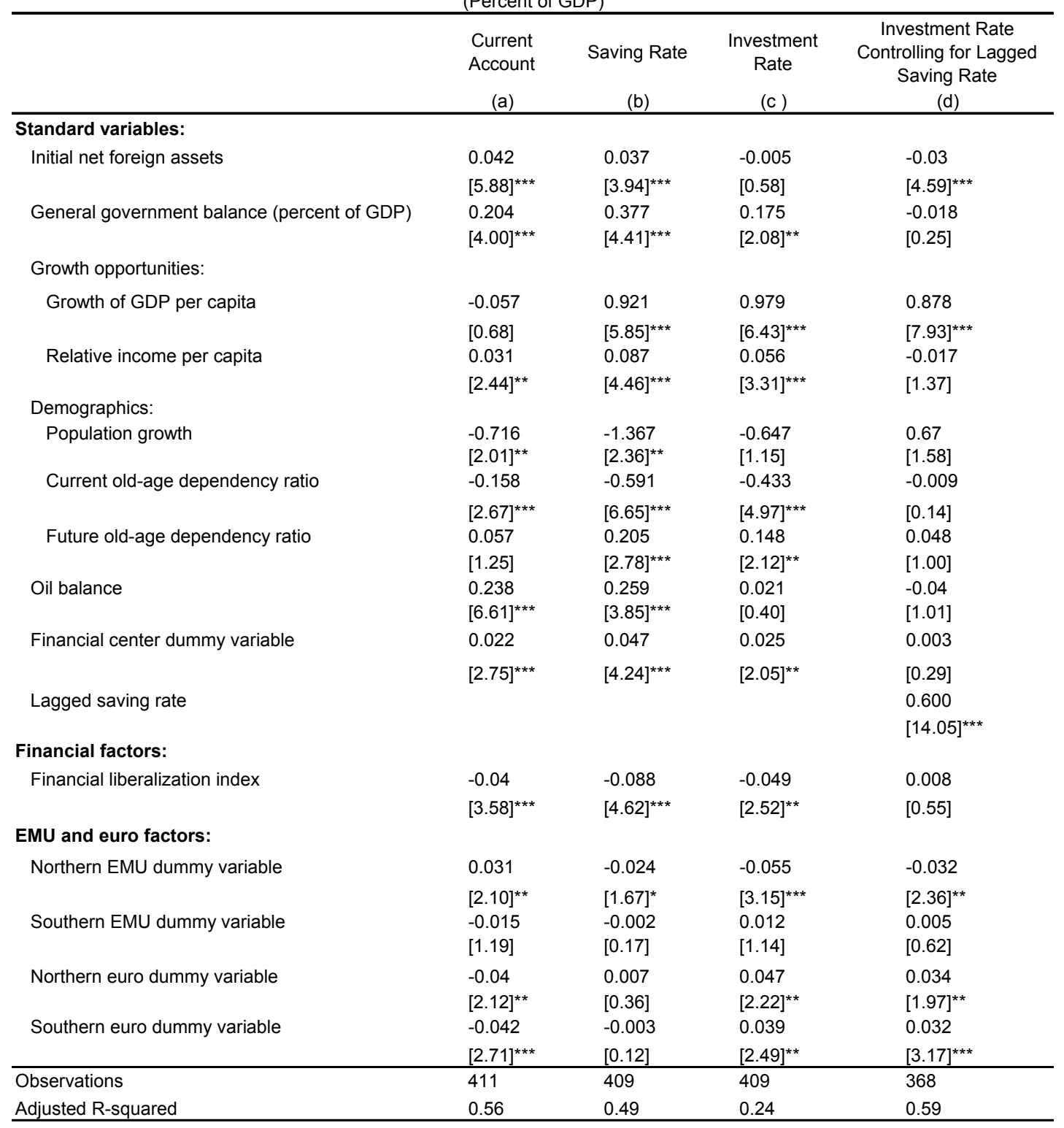

Source: IMF staff calculations.

$1 /$ Robust t statistics are in parentheses; * ${ }^{* *}$, and ${ }^{* * *}$ denotes significance at the 10 percent, 5 percent, and 1 percent, respectively. All regressions include a constant and time-fixed effects and are estimated by ordinary least squares. 
Decomposing the change in SEA current accounts between 1989-1992 and 2005-2008 into the contributions of the various variables shows that most of the decline is explained by the SEA-specific EMU/euro effects (Figure 13). ${ }^{21}$ Euro adoption allowed investment to be maintained at a much higher level than domestic saving would have financed with a broadly unchanged domestic saving rate. Hence, one benefit from economic integration was improved access to the international pool of saving. Financial liberalization also contributed to the decline in current accounts, but to a smaller extent (about 1 percentage point). While financial liberalization was a major factor behind the sharp drop in saving rates, the lower availability of domestic saving constrained investment, offsetting much of the effect on the current account. Demographic developments, in particular growing dependency ratios, also played a major role in the drop in saving rates, with a negative but limited effect on the current account due to the downward adjustment of investment (Figure 14).

With EMU and euro effects largely offsetting each other in NEA, the impact of the EMU-euro process and financial liberalization on current accounts were more moderate than for SEA, yielding a decline of about 1-2 percentage points. In Northern Europe, most of the increase in current accounts can be attributed to global factors that affected all countries at the same time (captured by time effects). The upward trend in their current accounts likely reflected the counterpart to the growing current account deficits of the United States over this period. Looking at the differences in levels of current accounts between SEA and NEA in the 2005-2008 period (instead of changes over time for each region) confirms that the EMU/euro factors were also the main contributors to the much lower current account in SEA, explaining about 40-50 percent (Figure 15).

\section{DO THE CURRENT ACCOUNT DEFICITS EXCEED NORMS?}

One natural question to ask is whether the current account deficits in SEA exceeded levels explained by fundamentals? We first take a look at the evolution of real effective exchange rates and growth performance subsequent to EMU entry. Acknowledging that increases in relative prices may not necessarily reflect a deterioration in competitiveness, we then turn to more formal measures of disequilibrium. We finish by looking at the likely effect of the global financial crisis on the current account deficits.

\section{Exchange rates and growth performance}

Simply looking at the evolution of real effective exchange rates (REER) shows strong real appreciations in SEA countries since the late 1990s. (Figure 16, Table 4). The price-based REER of SEA appreciated by 10-16 percent. That of NEA also appreciated, but to a lesser extent. Price-based REERs, however, may not fully reflect the underlying competitiveness

\footnotetext{
${ }^{21}$ The contribution of a determinant is calculated as the product of its coefficient and the change in the determinant's value between 1989-1992 and 2005-2008. It is worth noting that the model explains well the average current account behavior in both Northern and Southern Europe, as shown by the small average residuals.
} 
problem. REERs calculated from unit labor cost in manufacturing show a more serious deterioration of competitiveness in the SEA. The SEA experienced a real appreciation of around 25 percent between the late 1990s and 2008, whereas the NEA recorded a real depreciation of around 8 percent.

Table 4. Real Exchange Rate Developments 1/

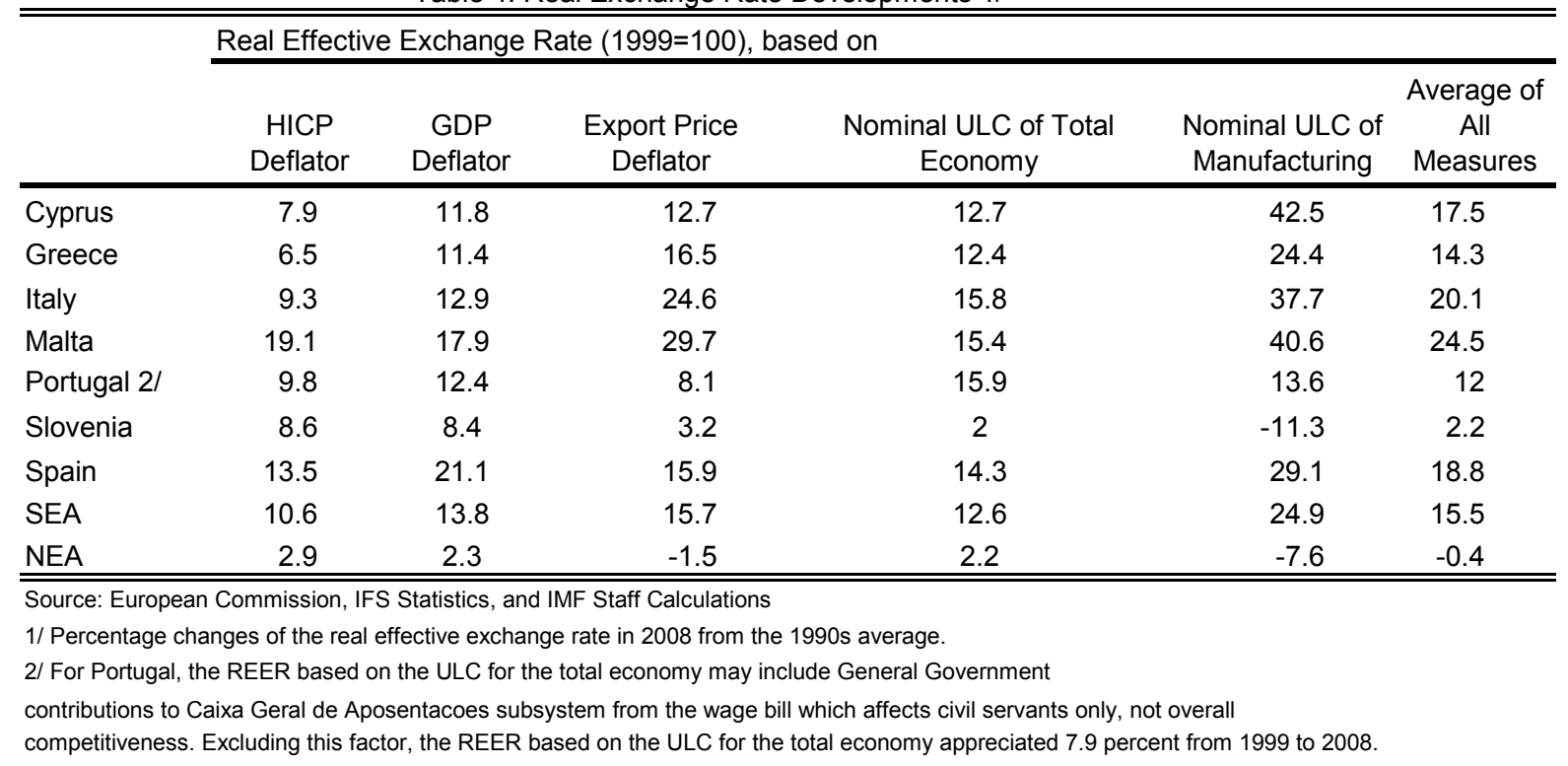

A factor symptom of a loss of competitiveness is the poor growth performance in SEA after entry into EMU when these large current account deficits were being accumulated (Figure 17). Growth per capita improved after EMU only in Greece, Slovenia and Cyprus, and declined in the other countries. ${ }^{22}$ Growth in SEA since 1994 was on average somewhat lower than in NEA and there is only mixed evidence of catching-up to NEA per capita income levels, despite lower initial income levels. ${ }^{23}$ One factor that appears correlated in SEA with the current account balance is a growing positive output gap. NEA countries experienced similar outputs gaps without deteriorations of their current accounts.

One argument often made in SEA countries is that relative prices may not be largely out of equilibrium since, at least, some of these countries have been doing well on export performance as measured by, for instance, export market shares. Although there is indeed some evidence of improvements in nonprice external competitiveness as examined in Bennett et al. (2008), looking at exports alone may be too narrow an indicator of competitiveness. To see this, one could do the following thought experiment: if it is not relative prices, but rather domestic demand, that is causing the excessive current account deficit, by how much would one need to reduce domestic demand (and increase unemployment) to bring the current account deficit down to more moderate and sustainable levels? The deep recession that such a reduction in current account deficits may require

\footnotetext{
${ }^{22}$ This result holds whether the cut-off year is 1990 or 1994 (stage 2 of EMU).

${ }^{23}$ Gourinchas (2002) also makes the point that convergence in the EMU seems to have stopped since 1996.
} 
would be a sign that demand management alone, without changing relative prices, would not seem feasible or optimal.

\section{Formal measures of competitiveness gaps}

The drawback of simply looking at the evolution of current accounts or REER is that it does not allow one to conclude whether the change reflected the adjustment to a new equilibrium (due to some fundamental change in the economy) or the emergence of a competitiveness problem. For instance, if a country is catching up on the value added ladder, this could lead to a faster rise in prices than in competitors which may not be symptomatic of a competitiveness problem. Rather, we can use the "Macro-Balance" (MB) and "External Sustainability" (ES) methodologies from the IMF CGER to determine an equilibrium current account and infer whether the actual current account gap is out of line with one based on underlying long-term fundamentals.

The MB approach calculates the equilibrium current account ("norm") as the predicted value of a current account regression including fundamental determinants of saving and investment. ${ }^{24}$ The norms are calculated for 2008, latest year for which we have actual data, using our regression model from Table 3. In contrast, the ES approach calculates the current account which stabilizes net foreign assets at some reference level (usually the latest observed value) and only requires a few assumptions, i.e. the medium-term real GDP growth rate $(g)$ and medium-term inflation $(\pi) .{ }^{25}$ The relationship between the current account norm and net foreign assets can be expressed as follows:

$C A^{E S} \approx \frac{g+\pi}{1+g+\pi} N F A .^{26}$

The MB and ES norms are then compared to the actual 2008 current account deficit corrected for the cycle ("underlying current account"). ${ }^{27}$ One issue is whether or not to include the

\footnotetext{
${ }^{24}$ To check for robustness, "steady state" current account norms are also calculated from a regression including current account dynamics as shown in Table 9(column b). The steady state current account norms excluding EMU and euro dummies are broadly in line with the corresponding MB norms and ES norms reported in Table 5. However, the steady state current account norms including EMU and euro dummies are even higher (in absolute value) than the corresponding MB norms reported in Table 5.

${ }^{25}$ When external assets and liabilities are primarily denominated in domestic currency, the domestic inflation is appropriate. Otherwise, the foreign inflation would perform better because, in some cases, the use of domestic inflation could overstate the ability of a country to run deficits (see Lee et al., 2008).

${ }^{26}$ The ES analysis implies that debtor economies that grow faster can afford to run larger current account deficits without deteriorating their external position.

${ }^{27}$ The current account norms are calculated for 2008. For comparison with the norm, the actual current account needs to be corrected for the fact that the output gaps both domestically and in partner countries were not zero in 2008. The correction for the output gaps is the following.
}

$C A^{p} / Y^{p}=C A / Y+\left[\left\{\left(G A P^{*} \cdot X \cdot \xi^{X}-G A P \cdot M \cdot \xi^{M}\right) /(Y .(1+G A P))\right\}-(C A / Y) \cdot G A P\right]$ 
EMU and euro dummy variables in the calculation of the MB norms. Average MB norms for the SEA vary from -6.4 percent of GDP when EMU and euro effects are included (as in CGER estimates) to -0.7 percent of GDP when they are not included (Table 5, Figure 18). True, the euro area allows bigger deficits than otherwise but how much of this should be considered as an equilibrium phenomenon? According to the ES approach, the average of SEA norms is about -1.5 percent, interestingly close to the estimates from the MB approach without the EMU and euro dummies. Thus, the ES approach suggests that the normative value of equilibrium CA balances with EMU and euro dummies is doubtful, as they lead to ever deteriorating international investment positions.

Table 5. Current Account Norms (Percent of GDP)

\begin{tabular}{lr}
\hline \hline & SEA Average 1/ \\
\hline Current Accounts in 2008 & -9.0 \\
Underlying Current Account 2/ & -8.4 \\
Estimated MB Norm with EMU/Euro Dummies & -6.4 \\
Estimated MB Norm without EMU/Euro Dummies & -0.7 \\
ES Norm 3/ & -1.5 \\
\hline \hline
\end{tabular}

Source: IMF Staff Calculations

$1 /$ SEA averages are unw eighted arithmetic means.

2/ The current account balance that w ould emerge at zero output gaps both domestically and in partner countries, i.e., the current account adjusted for the presence of output gaps in 2008.

3/ The current account balance that w ould stabilize the NFA-to-GDP ratio at its average level in2007-2008.

Both the MB and ES norms point to a substantial competitiveness gap for the region as a whole as 2008 current account deficits are substantially larger than the norms, though with substantial variation across countries (with the gap being largest for Cyprus, Greece and Portugal and smallest for Italy, Slovenia and Spain). And it is important to note that the ES norms only stabilize net foreign assets at existing levels, which for many of the SEA countries are already very low; hence, they are not particularly demanding. ${ }^{28}$ The MB approach offers a view on the factors underlying SEA current account norms (Table 6). For the region as a whole, the high degree of financial liberalization, the weak net foreign asset positions, and higher growth opportunities are the main contributors to the negative current account norms.

\footnotetext{
where

$C A / Y$ current account balance as percent of GDP

$C A^{p} / Y^{p} \quad$ current account balance as percent of GDP adjusted for output gaps

$G A P \quad$ the country's output gaps

$G A P^{*} \quad$ the weighted average of trading partners' output gaps

$X \quad$ export value $\quad \xi^{X} \quad$ an elasticity of exports to foreign output gaps

$M \quad$ import value $\quad \xi^{M} \quad$ an elasticity of imports to the country's output gaps.

${ }^{28}$ This concept is not too different from debt sustainability conditions in fiscal analysis. It does not tell you whether that debt level is in any way relevant or sustainable.
} 
Table 6. Contributions to SEA Current Account Norms in 2008

\begin{tabular}{lr}
\hline \hline & SEA average 1/ \\
\hline Initial net foreign assets & -1.6 \\
Fiscal balance & -0.1 \\
Growth opportunities & -1.3 \\
Demographics & -0.2 \\
Financial factors & -3.4 \\
Other variables & -1.3 \\
Time dummy and constant & 7.3 \\
Current account norms without EMU/Euro dummies & -0.7 \\
EMU and euro factors & -5.7 \\
Current account norms with EMU/Euro dummies & -6.4 \\
\hline \hline
\end{tabular}

Source: IMF Staff Calculations

1/ SEA Averages are unweighted arithmetic means.

\section{Impact of the global financial crisis}

The global financial crisis which started in July 2007 is forcing some unwinding of current account imbalances (Figure 19). Domestic demand has been contracting sharply in SEA countries, while net exports have provided some cushion to growth as the fall in domestic demand has caused imports to collapse. As imports are much greater than exports in most SEA, the improvement in the underlying current accounts has been large, on average 3 percentage points of GDP, with the largest improvement observed in Spain, though again with substantial variation across countries. This results in estimates of competitiveness gaps being significantly lower than those calculated for 2008 .

Despite the adjustment triggered by the crisis, external positions in SEA are expected to remain vulnerable. Expected adjustments in outer years are on the whole gradualand current account deficits will stay relatively high in the medium-run and would continue to require sizeable international financing.

\section{POLICY OPTIONS IN A CURRENCY UNION}

Why should a country worry about a large current account deficit in a currency union, where presumably there is no exchange rate risk? There are at least three reasons. ${ }^{29}$

First, because it may reflect domestic distortions (Blanchard, 2007; Blanchard and Milesi-Ferretti, 2009). Examples of this are low net savings resulting from transitory booms in asset prices (Spain) or excessively rosy expectations about future growth (Portugal in the late 1990s). ${ }^{30}$

\footnotetext{
${ }^{29}$ Guyon (2007), for example, also warns about the dangers from excessive current accounts in a monetary union and discusses policy options to reduce them.

${ }^{30}$ See Blanchard (2006) for an in-depth discussion of the case of Portugal. It should be noted that this occurred in a relatively contained period and was thus not a major determinant of current account developments later on.
} 
Second, because gradual adjustment is painful. A current account deficit that results from competitiveness problems and/or overheating would likely require a protracted period of low growth to recover from them afterwards. This is especially true in a currency union, where competitiveness can only be reestablished slowly through containing wage costs and boosting productivity, and where labor mobility and flexibility is limited and there is only limited fiscal transfer across countries in Europe. ${ }^{31}$

Third, because adjustment may be abrupt rather than gradual. If financing suddenly stops or becomes expensive, countries with large current account deficits are forced to deleverage intensely causing a sharp contraction of domestic demand (see also Gourinchas, 2002). The financing problem may be compounded by vulnerabilities on the asset side of the banking sector's balance sheet, as the rapid credit growth that underlined the accumulation of current account deficits was associated with lower average loan quality. And, the contraction of the economy induced by the abrupt reduction of financing increases nonperforming loans, further increasing the vulnerability of the banking sector.

Hence, we argue that it is desirable for SEA countries to reduce their current account deficits on a structural basis. But what policies can be used if the nominal exchange rate is not available? There are automatic built-in adjustment processes in a currency union, such as the competitiveness channel. ${ }^{32}$ Countries that have lost price competitiveness will eventually experience recessionary forces that help re-establish competitiveness via lower inflation/costs. That being said, the functioning of the competitiveness channel may be slow and delayed considerably, as long as an endogenous financing of balance of payment needs is available. And, the cost of having accumulated large external liabilities may suddenly increase, if the risk appetitive of international investors drops. The lags and costs associated with the automatic adjustment process are an argument for taking corrective policy measures in case of large current account deficits. Policy options include fiscal adjustment, "internal devaluation," productivity-enhancing policies, especially in the nontradable sector, and regulatory financial policies.

- Fiscal policy is perhaps the most important macroeconomic policy tool, especially where monetary policy is centralized. Fiscal consolidation seems particularly appropriate if public saving is too low or monetary policy too lax, which may well have been the case for SEA countries. While SEA countries consolidated their fiscal position to enter the euro area, these efforts were not sustained to offset the strong declines in private saving and private investment booms that followed, leading to big current account deficits. And the apparent strength of some fiscal positions during the boom was overstated by

\footnotetext{
${ }^{31}$ Decressin and Stavrev (2008) provide evidence that the speed of adjustment of current accounts to their equilibrium has slowed in EMU countries following the introduction of more rigid exchange rate policies in 1992.

${ }^{32}$ Another one is the risk channel: in a currency area, economic agents can better mitigate country-specific shocks through portfolio diversification.
} 
unsustainably inflated revenues from booming sectors such as construction (e.g., Spain). Fiscal consolidation will remain crucial going forward, to reverse the extensive use of fiscal stimuli and automatic stabilizers during the crisis, to lower the public debt and reduce domestic demand pressure. ${ }^{33}$ Fiscal policy should also reduce or eliminate policies that may previously have been distorting private saving and investment decisions (e.g. mortgage interest relief, favorable tax treatment of debt).

- Structural policies to improve productivity growth, including in the nontradable sector, are crucial to regain competitiveness. Productivity growth depends on capital investment, education, innovation, product market regulation, labor market flexibility, and the business environment. Productivity growth is not only important in the tradable sector but also in the nontradable sector as it feeds into the costs of the tradable sector. Although their impact may be of a more medium-run nature, productivity-enhancing reforms are crucial to establish the future competitiveness and achieve a higher standard of living. Structural reforms, especially in product markets, should also permit (temporarily) lower inflation.

- Another policy option is a so-called "internal devaluation", which mimics a real devaluation by reducing labor costs at home relative to trading partners. One instrument that has been used is lowering social security contributions financed by increasing VAT rates (thus switching the weight of tax bases), as was apparently successfully done by Germany in 2006. Labor costs can also be contained by reducing indexation of wages to inflation, as these tend to perpetuate a situation of high wage growth and high inflation, destroying competitiveness in a currency union. If, for political reasons, indexation cannot be reduced, one option would be to use the average inflation of the currency union as a peg for wage growth; yet, while this may help to stabilize competitiveness, it may not be sufficient to regain the lost competitiveness depending on the differential in productivity growth. ${ }^{34}$ Amending other wage impacting policies could also be of help: minimum wage growth and public wage growth could be moderated and unemployment benefits reassessed. ${ }^{35}$

- Regulatory financial policies are also important. The boom in Southern Europe was accompanied by rapid growth of private sector credit, with an accumulation of risks in financial assets as average loan quality was declining. By improving financial supervision and making provisioning more stringent in booms, central banks can limit the growth of private credit growth and the accumulation of dubious quality loans. The countercyclical loan-loss provisioning system applied by the Bank of Spain is one example which has received a lot of attention, as it helped build important provisioning cushions for hard

\footnotetext{
${ }^{33}$ For Spain, Catalan and Lama (2006) estimated that a reduction in real government spending by 1.5 percentage point of GDP would improve the current account balance by 1 percentage point of GDP.

${ }^{34}$ Thus, in that case, it would be better to index to the lowest inflation country in the union, but this is also politically difficult to do.

${ }^{35}$ Perez and Sanchez (2010) found strong evidence that public wages play a signaling role for private wages in four main euro area economies, i.e. Germany, France, Italy and Spain.
} 
times. Yet, as Spain demonstrates, even these tough regulatory standards are not a panacea and financial regulation by itself cannot completely protect the financial markets or the economy. ${ }^{36}$

The impact that some of these policies can have on the current account can be illustrated using the quantitative analysis developed in this paper (Table 7) (see the Appendix for detailed analysis). For instance, if Italy, Portugal and Spain were to bring their labor productivity growth to the highest levels observed in NEA (Finland and Netherlands), this would boost their current accounts by $2-2.5$ percentage points of GDP. If in addition, Greece and Portugal were to moderate minimum wage increases to lower their ratio of minimum to mean wage to the lowest level in the NEA (Austria, Germany, Finland), their current accounts would improve by a further $2-2.5$ percentage points. ${ }^{37}$ These indicative calculations suggest that the impact of appropriate policy adjustments can be large.

Table 7. The Improvement in Current Accounts from Policy Changes

\begin{tabular}{lrrrrr}
\hline \hline & \multicolumn{2}{c}{ ratio of min to mean wage 1/ } & \multicolumn{2}{c}{ labor productivity growth 2/ } \\
\cline { 2 - 5 } & \multicolumn{2}{c}{ avg NEA } & min NEA & avg NEA & max NEA \\
\hline Italy & -1.1 & 0.0 & 1.9 & 2.6 \\
Greece & 1.0 & 2.1 & -1.1 & -0.4 \\
Portugal & 1.4 & 2.5 & 0.8 & 1.6 \\
Spain & 0.0 & 1.1 & 1.7 & 2.4 \\
\hline \hline
\end{tabular}

Source: IMF Staff Calculation

1/ Each country lowers its ratio of minimum to mean wage to the lowest/average level in the NEA (Austria, Germany, Finland)

2/ Each country brings its labor productivity growth to the highest/average levels observed in NEA (Finland and Netherlands)

\footnotetext{
${ }^{36}$ The chances of a prudent regulation containing the growing imbalances in Spain were limited since it needed to compensate both the interest rate and exchange rate shocks of the euro introduction and the strong structural factors behind the real estate boom (fiscal incentives to property and land development speed).

${ }^{37}$ The magnitude of this effect suggests that the minimum wage may also be picking up other labor market rigidities.
} 


\section{CONCLUSIONS}

Most of the decline in current accounts in the SEA since the mid-1990s reflected a decline in private saving rates, spurred by financial liberalization and increasing dependency ratios. But the decline in current accounts would not have occurred, despite the decrease in saving rates, were it not for EMU and the euro. The euro helped SEA countries which had lower starting incomes to maintain investment despite lower saving rates by improving their access to international saving. That does not necessarily imply that the extent of borrowing that took place was optimal or sustainable.

Indeed, SEA current account deficits in 2008 exceeded their long-run fundamental "norms." At best, adjusting deficits is painful, given factor market rigidities, and at worst can be abrupt. The recent global financial crisis has begun to force some unwinding, but further corrections are needed. This calls for a policy response. Possible instruments include fiscal consolidation, "internal devaluation," structural policies to boost growth, and tighter regulatory policies. Our estimates suggest that raising labor productivity and moderating unit labor costs (in particular, minimum wages) could substantially improve current positions. 


\section{REFERENCES}

Abiad, Abdul, Enrica Detragiache and Thierry Tressel, 2008, “A New Database of Financial Reforms.” IMF Working Paper 08/266.

Abiad, Abdul, Daniel Leigh, and Ashoka Mody, 2007, “International Finance and Income Convergence: Europe is Different.” IMF Working Paper No. 07/64. Washington: International Monetary Fund, March.

Aleksynska, Mariya, and Martin Schindler, 2009, "Labor Market Institutions in Advanced and Developing Countries: A New Panel Database," IMF Working Paper, forthcoming.

Bennett, Herman, Julio Escolano, Stefania Fabrizio, Eva Gutiérrez, Iryna Ivaschenko, Bogdan Lissovolik, Marialuz Moreno-Badia, Werner Schule, Stephen Tokarick, Yuan Xiao, and Ziga Zarnic, 2008, "Competitiveness in the Southern Euro Area: France, Greece, Italy, Portugal, and Spain”, IMF Working Paper 08/112

Blanchard, Olivier, and Francesco Giavazzi, 2002, "Current Account Deficits in the Euro Area. The End of the Feldstein Horioka Puzzle?," Brookings Papers on Economic Activity, Vol. 2002, No. 2, pp. 147-209.

Blanchard, Olivier, 2006, "Adjustment Within the Euro: The Difficult Case of Portugal," MIT Economics Working Paper No. 06-04, Cambridge, Massachusetts. Also published in Portuguese Economic Journal, February 2007.

Blanchard, Olivier, 2007, "Current Account Deficits in Rich Countries", IMF Staff Papers, Vol.54, No.2, p.191-219.

Blanchard, Olivier, and Gian Maria Milesi-Ferretti, 2009, "Global Imbalances: Past, Present, and Future," note for the "Istanbul papers" on current macro and financial issues.

Calderón, César, Alberto Chong, and Norman Loayza, 2000, "Determinants of Current Account Deficits in Developing Countries", Policy Research Working Paper 2398, The World Bank.

Catalán, Mario and Ruy Lama, 2006, "Fiscal Policy and the External Balance in Spain”, Selected Issues, IMF Country Report No. 06/213.

Ca' Zorzi, Michele, Alexander Chudik, and Alistair Dieppe, 2009, “Current Account Benchmarks for Central and Eastern Europe: a Desperate Search?”, ECB Working Paper No. 995.

Chinn, Menzie, and Hiro Ito, 2006, "What Matters for Financial Development? Capital Controls, Institutions, and Interactions," Journal of Development Economics, Vol. 81 (October), pp. 163-92. Available via the Internet: www.web.pdx.edu/ ito. 
Chinn, Menzie D., and Eswar S. Prasad, 2003, "Medium-term Determinants of Current Accounts in Industrial and Developing Countries: An Empirical Exploration,” Journal of International Economics, Vol. 59, pp. 47-76.

Danninger, Stephan, and Florence Jaumotte, 2008, "Divergence of Current Account Balances Across Emerging Economies”, IMF October 2008 World Economic Outlook.

Decressin Jorg and Emil Stavrev, 2009, "Current Accounts in a Currency Union”, IMF Working Papers 09/127.

Gourinchas, Pierre-Olivier, 2002, "Comments on Current Account Deficits in the Euro Area. The End of the Feldstein-Horioka Puzzle," Brookings Papers on Economic Activity, Iss.2, p.196-206.

Gruber, Joseph W. and Steven B. Kamin, 2007. "Explaining the Global Pattern of Current Account Imbalances," Journal of International Money and Finance, No 26, 500-522.

Gruber, Joseph W. and Steven B. Kamin, 2008. "Do Differences in Financial Development Explain the Global Pattern of Current Account Imbalances?" International Finance Discussion Papers Number 923. Board of Governors of the Federal Reserve System: March.

Guyon, Thibault, 2007, "Should We Worry about Current Account Imbalances in a Monetary Union?”, La Lettre Trésor-Economics, No.2, p.1-8.

Lee, Jaewoo, Gian Maria Milesi-Ferretti, Jonathan Ostry, Alessandro Prati, and Luca Antonio Ricci, 2008. "Exchange Rate Assessments: CGER Methodologies." IMF Occasional Paper No. 261. Washington: International Monetary Fund.

Perez, Javier J. and A. Jesus Sanchez, 2010, "Is There a Signaling Role for Public Wages? Evidence for the Euro Area Based on Macro Data", ECB Working Paper No. 1148. 


\section{APPENDIX}

This appendix explains in more detail the quantitative analysis performed in the paper. It presents the current account specification used for the regression analysis, the variable definitions and data sources, the estimation results and robustness tests for the current account regressions, the estimation results for the saving and investment rates regressions, and finally the estimation of the impact of some policy proxies on the current account.

\section{The specification}

In order to investigate the impact of EMU, the paper uses a standard current account regression which controls for a broad set of determinants of current accounts and augments it with a set of additional variables that capture EMU formation. Standard current account regressions include a number of factors that have been highlighted in the literature as important determinants of current account balances, through their impact on saving and investment (see for instance Lee et al., 2008). These determinants include the fiscal balance, population growth, the old-age dependency ratio, the initial net foreign asset position, and growth opportunities proxied by per capita income levels and growth of income per capita. Growth opportunities are expected to lower the current account through higher investment and lower saving. Population growth and the old-age dependency ratio should also lower the current account by lowering saving. While standard models only include the current old-age dependency ratio, this paper also examines the effect of the future old-age dependency ratio (15 years from now), as a higher expected old-age dependency ratio in the future may prompt to save now. In contrast, a fiscal surplus will raise the current account if it is not fully offset by a decrease in private saving and/or a rise in private investment. Finally, higher net foreign assets are expected to raise the current account by increasing net investment income. The regression also includes a dummy variable for financial centers as these typically export capital, the oil balance, and time effects to capture developments that affect similarly all countries in a given time period.

The standard model is then augmented to test for the effect of EMU in two major ways. First, it introduces indicators of financial liberalization. They are expected to have a negative impact on current accounts by lowering saving and raising investment. Second, it introduces dummy variables for participation into EMU and adoption of the euro. In order to allow participation into the EMU and euro adoption to have different impacts on Northern and Southern countries, both the EMU and euro dummy variables are further split into North and South. These dummy variables are meant to capture other channels through which EMU may have affected current accounts such as improved macroeconomic policies and lowered country risk premia. Although the role of interest rates will be examined below, interest rates are not part of the preferred specification due to obvious concerns of endogeneity. The estimated specification thus reads:

$$
\begin{aligned}
& \frac{C A}{Y}=\alpha_{1}+\alpha_{2}\left(\frac{N F A}{Y}\right)+\alpha_{3}\left(\frac{G G B}{Y}\right)+\alpha_{4}\left(\frac{N X_{\text {oil }}}{Y}\right)+\alpha_{5}\left(\frac{P o p_{\text {old }}}{P o p_{\text {wa }}}\right)+\alpha_{6} g_{\text {pop }} \\
& +\alpha_{7}\left(\frac{y}{y_{U S}}\right)+\alpha_{8}\left(g_{y}\right)+\sum_{k} \beta_{k} X_{k}+\gamma_{3} F C+\sum_{l} \delta t_{l}+\mathcal{E},(1)
\end{aligned}
$$


where $C A$ is the current account balance, $Y$ is nominal GDP, $N F A$ are net foreign assets, $G G B$ is the general government balance, $N X_{\text {oil }}$ is the oil balance, $P_{o p}$ old is the population of ages 65 and over, $P o p_{w a}$ is the working-age population, $g_{p o p}$ is the population growth rate, $y$ is GDP per capita in constant PPP terms, $g_{y}$ is the growth rate of real per capita income, $F C$ is a dummy variable taking the value 1 for financial centers, $t$ are time fixed effects and $X$ denotes the range of new factors added to the standard model in several stages. The general government balance, demographic variables and income per capita growth are expressed in deviation from the trade-weighted average of trading partners. The specification is estimated using ordinary least squares with heteroskedasticity-consistent standard errors.

\section{Variable Definitions and Data Sources}

The determinants of the current account are classified into four main categories.

- The standard variables are from Lee et al. (2008) as updated by the IMF research department.

- The financial factors consist of the financial liberalization index and the capital account openness. The two measure the degree of financial liberalization. The higher the index, the more liberalized the financial market. The first indicator is from Abiad et al. (2008) and the second from Chinn and Ito (2006).

- EMU and euro factors are the dummy variables to capture the structural changes around the EMU entry and the euro adoption. The EMU dummy variable takes the value one for the years where the country belongs to EMU (starting from the more formal second stage) and zero otherwise. The euro dummy variable takes the value one for the years where the country uses the euro and zero otherwise. The EMU-North dummy variable takes the value one during EMU years for "Northern" countries, EMU-South takes the value one during EMU years for "Southern" countries, and similarly for the euro dummy variables. The dates of the EMU and the euro adoption are from the European Commission.

- Other structural factors include employment protection legislation, the ratio of minimum to mean wage, unemployment benefit replacement rate, and labor productivity growth. The policy indicators are from Aleksynska and Schindler (2009), while labor productivity growth calculations are based on IMF WEO data.

\section{Estimation results for the current account}

Estimating the standard model confirms that the current account is lowered by fiscal deficits, growth opportunities, high current values of dependency ratios and low net foreign assets (Table 8 , column a). Most variables have the expected sign and are significant. While growth of income per capita is insignificant, ${ }^{38}$ the other indicator of growth opportunities - the level of income per capita (scaled by the US level) - is significant. The results also confirm that

\footnotetext{
${ }^{38}$ CGER only includes this variable for emerging countries; however, given its potential importance for Southern European countries, it was included for all countries in this paper.
} 
the future value of the old-age dependency ratio increases the current account, in contrast to current values of the old-age dependency ratio which decrease it. It is worth noting that the coefficients on the time dummies (not reported in the table) increase over time, suggesting that the sample average of current accounts increases over time. This likely reflects the growing financing needs of the United States, which were met by improving current accounts in a larger number of smaller countries.

Turning to the impact of EMU-related variables, financial liberalization is found to lower the current account. This effect is confirmed whether one uses the broad financial liberalization index or the narrower indicator of capital account openness. However, when both measures are introduced simultaneously, only the broader indicator is significant (Table 8, columns b-d). The EMU and euro dummy variables are also significant, suggesting an additional impact of EMU and euro adoption on the current accounts (Table 8, columns e-g). Introduced separately, the EMU and the euro dummies each have negative effects on the current account but of moderate size ( 1 to 2 percentage points). A clearer picture emerges when the specification introduces simultaneously EMU and euro dummies and allows different effects for Northern and Southern countries. On the one hand, EMU appears to have improved current accounts in the Northern countries by a sizeable amount (about 3 percentage points), while no significant effect is found for Southern countries. On the other hand, euro adoption tended to lower current accounts in both subregions, also by a sizeable amount (an additional 4 percentage points relative to the EMU effect).

The results on financial liberalization and EMU-euro effects are robust to a number of sensitivity tests (Table 9). These included: introducing country fixed effects, replacing initial net foreign assets by the lagged current account in order to better take into account the current account dynamics, clustering standard errors by country, outliers' tests, and instrumenting for potentially endogenous variables (growth of per capita income, relative income per capita, the fiscal balance, and the oil balance). Results were also robust to dropping one country at a time, one period at a time, and one variable at a time (available on request).

Adding the real interest rate to the estimated models does not change results significantly (not reported). The real interest rates on 10-year government bonds have a positive and significant effect on the current account, which suggests that the declines in real interest rates in SEA have contributed to the declines in current accounts in this region. ${ }^{39}$ However, the estimated magnitude of the effect is not large, about 1 percentage point for the change in the current accounts between 1989-1992 and 2005-2008. It could be underestimated though due to the endogeneity of interest rates. Using the first and second lag of the interest rate as instruments suggests a somewhat larger effect (about 40\% higher); however the coefficient is not significant.

\footnotetext{
${ }^{39}$ The introduction of interest rates does not affect much other coefficients, although the much smaller sample size does. The EMU and euro dummy variables are still jointly significant.
} 


\section{Determinants of saving and investment}

To gain a better understanding of the channels at work, the analysis looks next at the impact of the variables examined so far on the saving and investment behavior underlying the current account (see Table 3). The current account is replaced in turn by the saving and investment rates in equation (1). The preferred regression for the investment rate also controls for the lagged saving rate, as many of the coefficients in the investment regression appear to be influenced by the savings rate equation. The saving rate is positively impacted by high net foreign assets, fiscal surpluses, high growth per capita, high per capita income levels, lower current dependency ratios and higher future dependency ratios. The investment rate in turn increases with higher growth per capita and lower net foreign assets, and a higher lagged saving rate.

Three interesting findings related to EMU variables emerge. First, financial liberalization has a strong negative effect on the savings rate and no significant effect on the investment rate, once the lagged saving rate is controlled for. Second, the EMU-euro effect on Southern Europe was mostly by raising the investment rate, while it had no significant impact on saving. Third, EMU reduced both saving and investment in Northern Europe but euro adoption led to a rebound of investment in Northern Europe.

Re-estimating the saving and investment equations as a system using seemingly unrelated regressions yield broadly similar results, although the euro dummies are somewhat less significant in the investment equation (joint $\mathrm{p}$-value of 11 percent).

\section{Impact of labor productivity growth and labor market policies}

The estimated model is used to test for the impact of some factors that proxy for policies on the current account and illustrate the magnitude of their effects (Table 10). Due to data constraints, the focus is on a few labor market indicators and labor productivity growth (not a policy variable per se but rather measuring the outcome of policies). Labor market indicators are available for the ratio of the minimum wage to the mean wage, the level of unemployment benefits and the level of employment protection legislation, with higher values indicating a higher degree of labor market liberalization. The regression finds evidence that higher minimum wages lower the current account, presumably by raising wage costs and reducing competitiveness. The other two variables are not statistically significant. Labor productivity growth is also found to have a large positive effect on the current account. ${ }^{40}$ The effect is larger and more significant when using the lagged value of labor productivity growth and especially when instrumenting labor productivity growth by its first and second lags to alleviate endogeneity issues.

\footnotetext{
${ }^{40}$ Growth of income per capita is dropped from the specification as it is correlated with labor productivity growth but insignificant.
} 
Table 8. Determinants of the Current Account Balance 1/ (Percent of GDP)

\begin{tabular}{|c|c|c|c|c|c|c|c|}
\hline \multirow[b]{2}{*}{ Standard variables: } & \multirow[t]{2}{*}{$\begin{array}{l}\text { Standard } \\
\text { model } \\
\text { (a) }\end{array}$} & \multicolumn{3}{|c|}{ Standard plus Financial Factors } & \multicolumn{3}{|c|}{ Standard Plus Financial and EMU/euro factors } \\
\hline & & & & & & & \\
\hline Initial net foreign assets & $\begin{array}{l}0.046 \\
{[6.99]^{\star * *}}\end{array}$ & $\begin{array}{l}0.045 \\
{[6.15]^{\star * *}}\end{array}$ & $\begin{array}{l}0.046 \\
{[6.13]^{\star * *}}\end{array}$ & $\begin{array}{l}0.045 \\
{[6.07]^{\star * *}}\end{array}$ & $\begin{array}{l}0.042 \\
{[5.72]^{* \star *}}\end{array}$ & $\begin{array}{l}0.041 \\
{[5.57]^{\star * *}}\end{array}$ & $\begin{array}{l}0.042 \\
{[5.88]^{\star \star \star}}\end{array}$ \\
\hline $\begin{array}{l}\text { General government balance (percent of } \\
\text { GDP) }\end{array}$ & 0.179 & & & & 0.194 & 0.202 & 0.204 \\
\hline & {$[3.44]^{\star * *}$} & {$[3.93]^{* * *}$} & {$[3.55]^{\star * *}$} & {$[3.96]^{\star * *}$} & {$[3.84]^{\star \star *}$} & {$[4.05]^{\star * *}$} & {$[4.00]^{\star \star *}$} \\
\hline \multicolumn{8}{|l|}{ Growth opportunities: } \\
\hline Growth of GDP per capita & $\begin{array}{l}-0.062 \\
{[0.70]}\end{array}$ & $\begin{array}{l}-0.042 \\
{[0.48]}\end{array}$ & $\begin{array}{l}-0.065 \\
{[0.72]}\end{array}$ & $\begin{array}{l}-0.05 \\
{[0.56]}\end{array}$ & $\begin{array}{l}-0.032 \\
{[0.37]}\end{array}$ & $\begin{array}{l}-0.038 \\
{[0.44]}\end{array}$ & $\begin{array}{l}-0.057 \\
{[0.68]}\end{array}$ \\
\hline Relative income per capita & $\begin{array}{l}0.022 \\
{[2.32]^{\star *}}\end{array}$ & $\begin{array}{l}0.039 \\
{[3.11]^{\star * *}}\end{array}$ & $\begin{array}{l}0.035 \\
{[2.91]^{\star * *}}\end{array}$ & $\begin{array}{l}0.042 \\
{[3.30]^{* * *}}\end{array}$ & $\begin{array}{l}0.039 \\
{[3.17]^{\star \star *}}\end{array}$ & $\begin{array}{l}0.04 \\
{[3.31]^{\star * \star}}\end{array}$ & $\begin{array}{l}0.031 \\
{[2.44]^{\star *}}\end{array}$ \\
\hline \multicolumn{8}{|l|}{ Demographics: } \\
\hline Population growth & $\begin{array}{l}-0.728 \\
{[2.01]^{\star \star}}\end{array}$ & $\begin{array}{l}-0.998 \\
{[2.78]^{\star \star *}}\end{array}$ & $\begin{array}{l}-0.742 \\
{[1.99]^{* *}}\end{array}$ & $\begin{array}{l}-1.007 \\
{[2.77]^{* * *}}\end{array}$ & $\begin{array}{l}-0.918 \\
{[2.59]^{\star * *}}\end{array}$ & $\begin{array}{l}-0.83 \\
{[2.33]^{\star *}}\end{array}$ & $\begin{array}{l}-0.716 \\
{[2.01]^{\star *}}\end{array}$ \\
\hline Current old-age dependency ratio & $\begin{array}{l}-0.276 \\
{[4.41]^{* * *}}\end{array}$ & $\begin{array}{l}-0.238 \\
{[3.84]^{\star * \star}}\end{array}$ & $\begin{array}{l}-0.26 \\
{[4.18]^{\star \star *}}\end{array}$ & $\begin{array}{l}-0.23 \\
{[3.76]^{\star \star *}}\end{array}$ & $\begin{array}{l}-0.22 \\
{[3.63]^{\star \star *}}\end{array}$ & $\begin{array}{l}-0.211 \\
{[3.47]^{\star * \star}}\end{array}$ & $\begin{array}{l}-0.158 \\
{[2.67]^{\star * *}}\end{array}$ \\
\hline Future old-age dependency ratio & $\begin{array}{l}0.109 \\
{[2.20]^{\star *}}\end{array}$ & $\begin{array}{l}0.065 \\
{[1.36]}\end{array}$ & $\begin{array}{l}0.093 \\
{[1.77]^{*}}\end{array}$ & $\begin{array}{l}0.06 \\
{[1.22]}\end{array}$ & $\begin{array}{l}0.073 \\
{[1.54]}\end{array}$ & $\begin{array}{l}0.072 \\
{[1.51]}\end{array}$ & $\begin{array}{l}0.057 \\
{[1.25]}\end{array}$ \\
\hline Oil balance & $\begin{array}{l}0.262 \\
{[7.12]^{\star \star *}}\end{array}$ & $\begin{array}{l}0.248 \\
{[6.83]^{\star \star \star}}\end{array}$ & $\begin{array}{l}0.266 \\
{[7.47]^{\star \star *}}\end{array}$ & $\begin{array}{l}0.251 \\
{[7.02]^{\star \star *}}\end{array}$ & $\begin{array}{l}0.247 \\
{[6.82]^{\star * *}}\end{array}$ & $\begin{array}{l}0.244 \\
{[6.76]^{\star * *}}\end{array}$ & $\begin{array}{l}0.238 \\
{[6.61]^{\star \star \star}}\end{array}$ \\
\hline Financial center dummy variable & $\begin{array}{l}0.016 \\
{[2.19]^{\star *}}\end{array}$ & $\begin{array}{l}0.02 \\
{[2.55]^{\star *}}\end{array}$ & $\begin{array}{l}0.022 \\
{[2.60]^{\star * *}}\end{array}$ & $\begin{array}{l}0.023 \\
{[2.82]^{\star \star \star *}}\end{array}$ & $\begin{array}{l}0.023 \\
{[2.86]^{\star \star *}}\end{array}$ & $\begin{array}{l}0.024 \\
{[3.04]^{\star \star \star}}\end{array}$ & $\begin{array}{l}0.022 \\
{[2.75]^{\star \star \star}}\end{array}$ \\
\hline \multicolumn{8}{|l|}{ Financial factors: } \\
\hline Financial liberalization index & & $\begin{array}{l}-0.038 \\
{[3.38]^{\star * *}}\end{array}$ & & $\begin{array}{l}-0.031 \\
{[2.37]^{\star *}}\end{array}$ & $\begin{array}{l}-0.039 \\
{[3.49]^{* * *}}\end{array}$ & $\begin{array}{l}-0.041 \\
{[3.73]^{* * *}}\end{array}$ & $\begin{array}{l}-0.04 \\
{[3.58]^{\star * *}}\end{array}$ \\
\hline Capital account openness & & & $\begin{array}{l}-0.003 \\
{[2.09]^{\star \star}}\end{array}$ & $\begin{array}{l}-0.002 \\
{[1.12]}\end{array}$ & & & \\
\hline EMU and euro factors: & & & & & & & \\
\hline EMU dummy variable & & & & & $\begin{array}{l}-0.013 \\
{[1.88]^{*}}\end{array}$ & & \\
\hline Euro dummy variable & & & & & & $\begin{array}{l}-0.023 \\
{[2.50]^{* *}}\end{array}$ & \\
\hline Northern EMU dummy variable & & & & & & & $\begin{array}{l}0.031 \\
{[2.10]^{\star *}}\end{array}$ \\
\hline Southern EMU dummy variable & & & & & & & $\begin{array}{l}-0.015 \\
{[1.19]}\end{array}$ \\
\hline Northern euro dummy variable & & & & & & & $\begin{array}{l}-0.04 \\
{[2.12]^{\text {** }}}\end{array}$ \\
\hline Southern euro dummy variable & & & & & & & $\begin{array}{l}-0.042 \\
{[2.71]^{* * *}}\end{array}$ \\
\hline Observations & 427 & 411 & 410 & 402 & 411 & 411 & 411 \\
\hline Adjusted R-squared & 0.53 & 0.54 & 0.55 & 0.56 & 0.54 & 0.55 & 0.56 \\
\hline
\end{tabular}

Source: IMF staff calculations.

$1 /$ Robust t statistics are in parentheses; *, **, and ${ }^{* * *}$ denotes significance at the 10 percent, 5 percent, and 1 percent, respectively.

All regressions include a constant and time-fixed effects and are estimated by ordinary least squares. 
Table 9. Robustness Tests of Current Account Regressions 1/

\begin{tabular}{|c|c|c|c|c|c|c|}
\hline \multicolumn{7}{|c|}{ (Percent of GDP) } \\
\hline & & $\begin{array}{l}\text { Benchmark Model } \\
\text { with Lagged } \\
\text { Current Account }\end{array}$ & $\begin{array}{l}\text { Estimation with } \\
\text { Country Fixed Effects }\end{array}$ & $\begin{array}{l}\text { Estimation with Standard } \\
\text { Errors Clustered by Country }\end{array}$ & $\begin{array}{c}\text { Estimation } \\
\text { Excluding Outliers }\end{array}$ & $\begin{array}{c}\text { Estimation by } \\
\text { Instrumental } \\
\text { Variables }\end{array}$ \\
\hline & (a) & (b) & (c) & (d) & (e) & (f) \\
\hline \multirow[t]{2}{*}{ Initial net foreign assets } & 0.042 & & 0.024 & 0.042 & 0.045 & 0.04 \\
\hline & {$[5.88]^{\star \star \star}$} & & {$[2.09]^{* *}$} & {$[4.56]^{\star \star \star *}$} & {$[8.30]^{* \star *}$} & {$[4.86]^{\star \star *}$} \\
\hline Lagged current account & & 0.541 & & & & \\
\hline \multicolumn{7}{|l|}{ Growth opportunities: } \\
\hline \multirow[t]{2}{*}{ Growth of GDP per capita } & -0.057 & -0.004 & -0.219 & -0.057 & -0.03 & 0.04 \\
\hline & {$[0.68]$} & {$[0.04]$} & {$[1.65]$} & {$[0.60]$} & [0.39] & {$[0.18]$} \\
\hline \multirow[t]{2}{*}{ Relative income per capita } & 0.031 & 0.031 & 0.091 & 0.031 & 0.019 & 0.04 \\
\hline & {$[2.44]^{\star \star}$} & {$[2.62]^{\star \star \star}$} & {$[1.30]$} & [1.54] & {$[1.65]^{\star}$} & {$[2.41]^{\star \star}$} \\
\hline \multicolumn{7}{|l|}{ Demographics: } \\
\hline Population growth & -0.716 & -0.495 & -1.365 & -0.716 & -0.734 & -0.588 \\
\hline \multirow[t]{2}{*}{ Oil balance } & 0.238 & 0.172 & 0.357 & 0.238 & 0.244 & 0.241 \\
\hline & {$[6.61]^{\star \star \star}$} & {$[4.59]^{\star \star \star}$} & {$[5.00]^{\star \star \star}$} & {$[10.21]^{\star \star \star}$} & {$[9.27]^{\star \star \star}$} & {$[5.68]^{\star \star *}$} \\
\hline \multirow[t]{2}{*}{ Financial center dummy variable } & 0.022 & 0.034 & & 0.022 & 0.025 & 0.031 \\
\hline & {$[2.75]^{\star \star \star}$} & {$[5.69]^{\star \star \star}$} & & {$[3.45]^{\star * *}$} & {$[3.51]^{* * *}$} & {$[3.90]^{\star * *}$} \\
\hline \multicolumn{7}{|l|}{ Financial factors: } \\
\hline \multirow[t]{2}{*}{ Financial liberalization index } & -0.04 & -0.030 & -0.048 & -0.04 & -0.031 & -0.041 \\
\hline & {$[3.58]^{\star \star \star *}$} & {$[2.52]^{\star \star}$} & {$[2.04]^{* *}$} & {$[2.79]^{\star \star *}$} & {$[2.76]^{* \star *}$} & {$[3.06]^{\star \star *}$} \\
\hline \multicolumn{7}{|l|}{ EMU and euro factors: } \\
\hline \multirow[t]{2}{*}{ Northern EMU dummy variable } & 0.031 & 0.018 & 0.014 & 0.031 & 0.034 & 0.028 \\
\hline & {$[2.10]^{\star *}$} & {$[1.38]$} & [0.63] & {$[1.67]$} & {$[2.29]^{\star *}$} & {$[1.92]^{*}$} \\
\hline \multirow[t]{2}{*}{ Southern EMU dummy variable } & -0.015 & -0.006 & 0.002 & -0.015 & -0.013 & -0.015 \\
\hline & {$[1.19]$} & {$[0.52]$} & {$[0.23]$} & {$[1.16]$} & {$[1.07]$} & {$[1.22]$} \\
\hline \multirow[t]{2}{*}{ Northern euro dummy variable } & -0.04 & -0.036 & -0.042 & -0.04 & -0.045 & -0.039 \\
\hline & {$[2.12]^{\star *}$} & {$[2.16]^{\star \star}$} & [1.61] & {$[1.60]$} & {$[2.41]^{\star \star}$} & {$[2.07]^{\star *}$} \\
\hline
\end{tabular}

$1 /$ Robust $t$ statistics are in parentheses; ${ }^{*}$, **, and ${ }^{* * *}$ denotes significance at the 10 percent, 5 percent, and 1 percent, respectively.

All regressions include a constant and time-fixed effects and are estimated by ordinary least squares, except column (e).

In column (e), the general government balance, growth of GDP per capita, relative income per capita, and the oil balance are instrumented using their first and second lags 
Table 10. Impact of Structural Policies on the Current Account $1 /$

\begin{tabular}{|c|c|c|c|c|c|}
\hline & $\begin{array}{c}\begin{array}{c}\text { Benchmark } \\
\text { model }\end{array} \\
\text { (a) }\end{array}$ & $\begin{array}{l}\text { Benchmark } \\
\text { Plus EPL } \\
\text { (b) }\end{array}$ & $\begin{array}{c}\text { Benchmark Plus } \\
\text { Minimum Wage } \\
\text { (c) }\end{array}$ & $\begin{array}{l}\text { Benchmark Plus } \\
\text { Unemployment } \\
\text { Benefits } \\
\text { (d) }\end{array}$ & $\begin{array}{c}\text { Benchmark Plus } \\
\text { All Labor Market } \\
\text { Variables } \\
\text { (e) }\end{array}$ \\
\hline \multicolumn{6}{|l|}{ Standard variables: } \\
\hline Initial net foreign assets & $\begin{array}{l}0.042 \\
{[5.88]^{\star * *}}\end{array}$ & $\begin{array}{l}0.041 \\
{[5.56]^{* * *}}\end{array}$ & $\begin{array}{l}0.036 \\
{[4.74]^{\star * *}}\end{array}$ & $\begin{array}{l}0.037 \\
{[5.08]^{\star * *}}\end{array}$ & $\begin{array}{l}0.033 \\
{[4.41]^{\star * *}}\end{array}$ \\
\hline $\begin{array}{l}\text { General government balance } \\
\text { (percent of GDP) }\end{array}$ & $\begin{array}{l}0.204 \\
{[4.00]^{\star * *}}\end{array}$ & $\begin{array}{l}0.184 \\
{[3.36]^{* * *}}\end{array}$ & $\begin{array}{l}0.191 \\
{[3.45]^{\star * *}}\end{array}$ & $\begin{array}{l}0.197 \\
{[3.58]^{\star * *}}\end{array}$ & $\begin{array}{l}0.199 \\
{[3.54]^{\star \star *}}\end{array}$ \\
\hline \multicolumn{6}{|l|}{ Growth opportunities: } \\
\hline Growth of GDP per capita & $\begin{array}{l}-0.057 \\
{[0.68]}\end{array}$ & $\begin{array}{l}-0.016 \\
{[0.17]}\end{array}$ & $\begin{array}{l}-0.035 \\
{[0.36]}\end{array}$ & $\begin{array}{l}0.009 \\
{[0.09]}\end{array}$ & $\begin{array}{l}-0.026 \\
{[0.26]}\end{array}$ \\
\hline Relative income per capita & $\begin{array}{l}0.031 \\
{[2.44]^{\star *}}\end{array}$ & $\begin{array}{l}0.036 \\
{[2.63]^{* * *}}\end{array}$ & $\begin{array}{l}0.025 \\
{[1.95]^{*}}\end{array}$ & $\begin{array}{l}0.03 \\
{[2.16]^{\star *}}\end{array}$ & $\begin{array}{l}0.018 \\
{[1.26]}\end{array}$ \\
\hline \multicolumn{6}{|l|}{ Demographics: } \\
\hline Population growth & $\begin{array}{l}-0.716 \\
{[2.01]^{\star *}}\end{array}$ & $\begin{array}{l}-0.772 \\
{[2.04]^{\star *}}\end{array}$ & $\begin{array}{l}-0.562 \\
{[1.39]}\end{array}$ & $\begin{array}{l}-0.553 \\
{[1.42]}\end{array}$ & $\begin{array}{l}-0.307 \\
{[0.73]}\end{array}$ \\
\hline Current old-age dependency ratio & $\begin{array}{l}-0.158 \\
{[2.67]^{\star \star *}}\end{array}$ & $\begin{array}{l}-0.183 \\
{[2.86]^{\star \star *}}\end{array}$ & $\begin{array}{l}-0.172 \\
{[2.73]^{\star * \star}}\end{array}$ & $\begin{array}{l}-0.151 \\
{[2.28]^{\star *}}\end{array}$ & $\begin{array}{l}-0.155 \\
{[2.29]^{\star *}}\end{array}$ \\
\hline Future old-age dependency ratio & $\begin{array}{l}0.057 \\
{[1.25]}\end{array}$ & $\begin{array}{l}0.059 \\
{[1.25]}\end{array}$ & $\begin{array}{l}0.081 \\
{[1.75]^{\star}}\end{array}$ & $\begin{array}{l}0.074 \\
{[1.55]}\end{array}$ & $\begin{array}{l}0.099 \\
{[2.11]^{\star *}}\end{array}$ \\
\hline Oil balance & $\begin{array}{l}0.238 \\
{[6.61]^{* * *}}\end{array}$ & $\begin{array}{l}0.231 \\
{[5.99]^{* * *}}\end{array}$ & $\begin{array}{l}0.234 \\
{[5.59]^{\star * *}}\end{array}$ & $\begin{array}{l}0.229 \\
{[5.97]^{\star \star *}}\end{array}$ & $\begin{array}{l}0.223 \\
{[5.23]^{\star * *}}\end{array}$ \\
\hline Financial center dummy variable & $\begin{array}{l}0.022 \\
{[2.75]^{\star \star \star}}\end{array}$ & $\begin{array}{l}0.025 \\
{[3.24]^{\star \star *}}\end{array}$ & $\begin{array}{l}0.029 \\
{[3.62]^{\star * *}}\end{array}$ & $\begin{array}{l}0.029 \\
{[3.60]^{\star \star *}}\end{array}$ & $\begin{array}{l}0.032 \\
{[3.69]^{\star * *}}\end{array}$ \\
\hline \multicolumn{6}{|l|}{ Financial factors: } \\
\hline Financial liberalization index & $\begin{array}{l}-0.04 \\
{[3.58]^{\star \star \star}}\end{array}$ & $\begin{array}{l}-0.042 \\
{[3.51]^{\star \star \star}}\end{array}$ & $\begin{array}{l}-0.049 \\
{[3.89]^{\star \star \star}}\end{array}$ & $\begin{array}{l}-0.044 \\
{[3.66]^{\star \star \star}}\end{array}$ & $\begin{array}{l}-0.049 \\
{[3.82]^{\star \star \star}}\end{array}$ \\
\hline \multicolumn{6}{|l|}{ EMU and euro factors: } \\
\hline Northern EMU dummy variable & $\begin{array}{l}0.031 \\
{[2.10]^{\star *}}\end{array}$ & $\begin{array}{l}0.03 \\
{[1.99]^{* *}}\end{array}$ & $\begin{array}{l}0.032 \\
{[1.97]^{* *}}\end{array}$ & $\begin{array}{l}0.028 \\
{[1.94]^{*}}\end{array}$ & $\begin{array}{l}0.03 \\
{[1.90]^{*}}\end{array}$ \\
\hline Southern EMU dummy variable & $\begin{array}{l}-0.015 \\
{[1.19]}\end{array}$ & $\begin{array}{l}-0.015 \\
{[1.16]}\end{array}$ & $\begin{array}{l}-0.011 \\
{[0.89]}\end{array}$ & $\begin{array}{l}-0.017 \\
{[1.32]}\end{array}$ & $\begin{array}{l}-0.012 \\
{[1.00]}\end{array}$ \\
\hline Northern euro dummy variable & $\begin{array}{l}-0.04 \\
{[2.12]^{\star *}}\end{array}$ & $\begin{array}{l}-0.039 \\
{[2.08]^{\star *}}\end{array}$ & $\begin{array}{l}-0.043 \\
{[2.29]^{\star *}}\end{array}$ & $\begin{array}{l}-0.042 \\
{[2.29]^{\star *}}\end{array}$ & $\begin{array}{l}-0.046 \\
{[2.49]^{* *}}\end{array}$ \\
\hline Southern euro dummy variable & $\begin{array}{l}-0.042 \\
{[2.71]^{\star * *}}\end{array}$ & $\begin{array}{l}-0.04 \\
{[2.54]^{\star *}}\end{array}$ & $\begin{array}{l}-0.046 \\
{[3.08]^{\star * *}}\end{array}$ & $\begin{array}{l}-0.044 \\
{[2.73]^{* \star *}}\end{array}$ & $\begin{array}{l}-0.051 \\
{[3.33]^{* * *}}\end{array}$ \\
\hline \multicolumn{6}{|l|}{ Structural factors: } \\
\hline Employment protection legislation2/ & & $\begin{array}{l}-0.001 \\
{[0.06]}\end{array}$ & & & $\begin{array}{l}0.008 \\
{[0.41]}\end{array}$ \\
\hline Ratio of minimum to mean wage $2 /$ & & & $\begin{array}{l}0.035 \\
{[3.86]^{* * *}}\end{array}$ & & $\begin{array}{l}0.036 \\
{[3.86]^{* * *}}\end{array}$ \\
\hline Unemployment benefit replacement rate2/ & & & & $\begin{array}{l}-0.006 \\
{[0.74]}\end{array}$ & $\begin{array}{l}-0.011 \\
{[1.14]}\end{array}$ \\
\hline \multicolumn{6}{|l|}{ Labor productivity growth } \\
\hline \multicolumn{6}{|l|}{ Lagged labor productivity growth } \\
\hline Observations & 411 & 370 & 346 & 358 & 334 \\
\hline Adjusted R-squared & 0.56 & 0.56 & 0.59 & 0.58 & 0.60 \\
\hline
\end{tabular}


Table 10 (continued): Impact of Structural Policies on the Current Account 1/ (Percent of GDP)

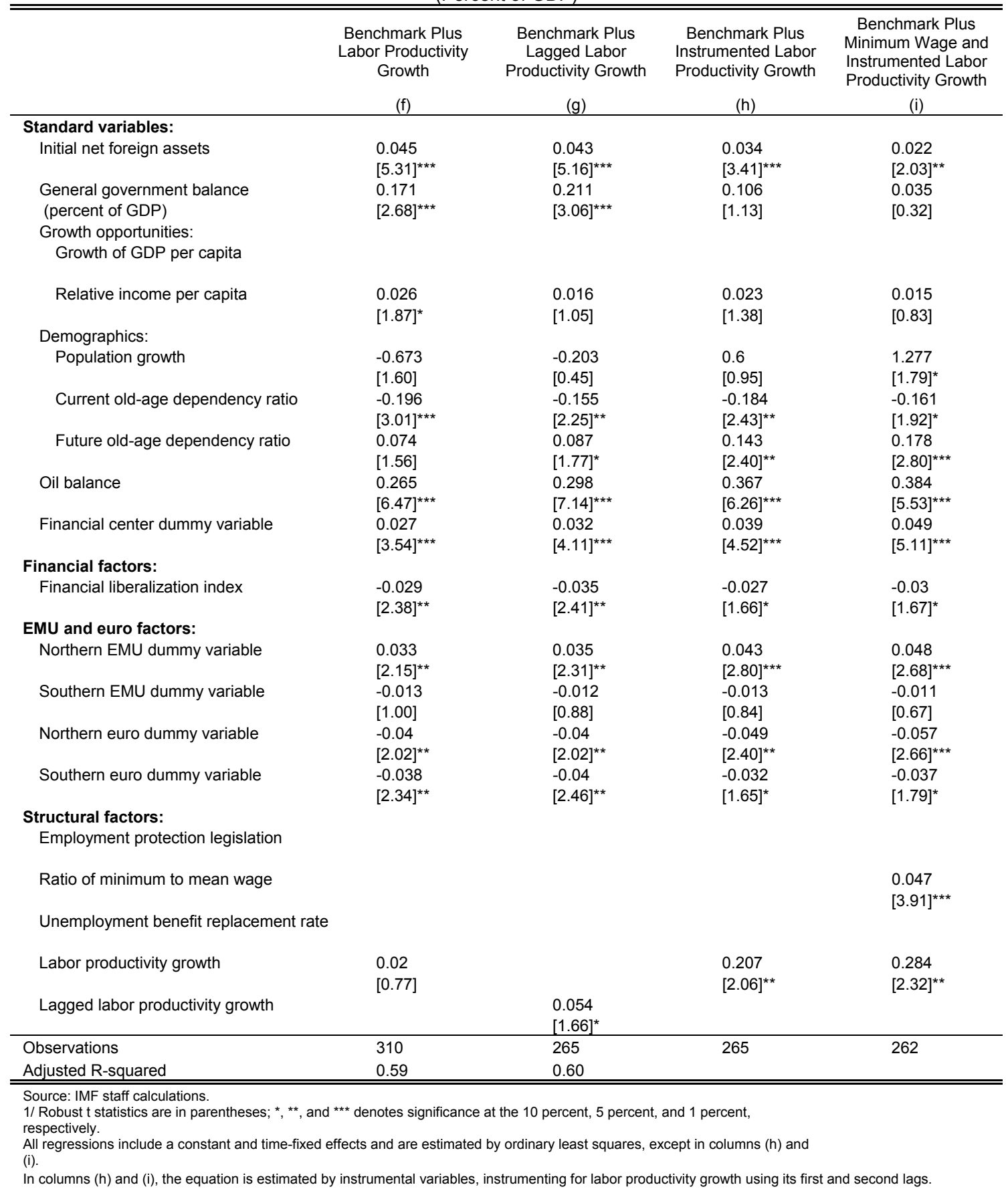


Figure 1. Euro Area: Current Account Balance 1/
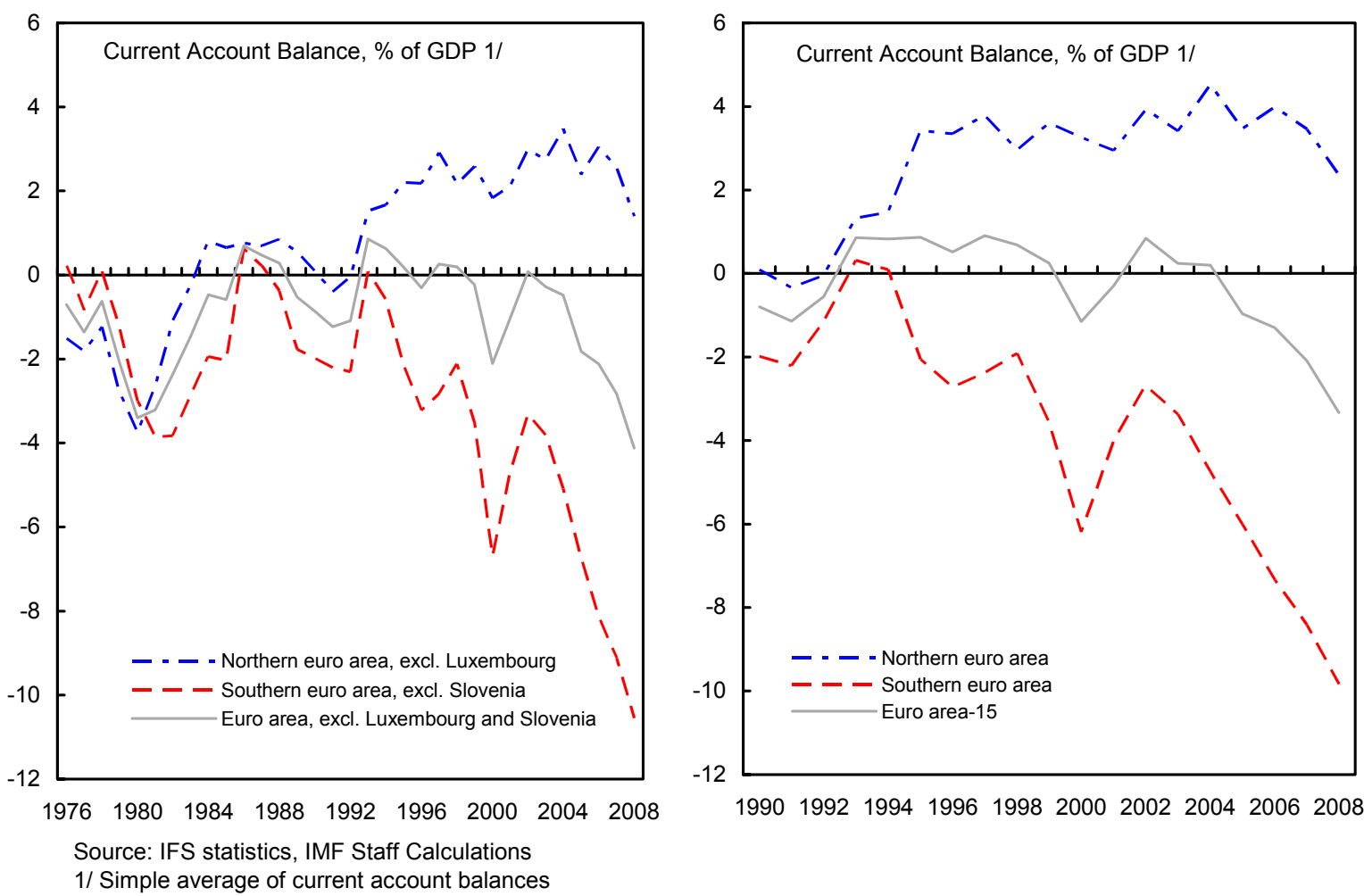

1990199219941996199820002002200420062008 
Figure 2. Southern Euro Area Countries: Current Account Balances 1970-2008
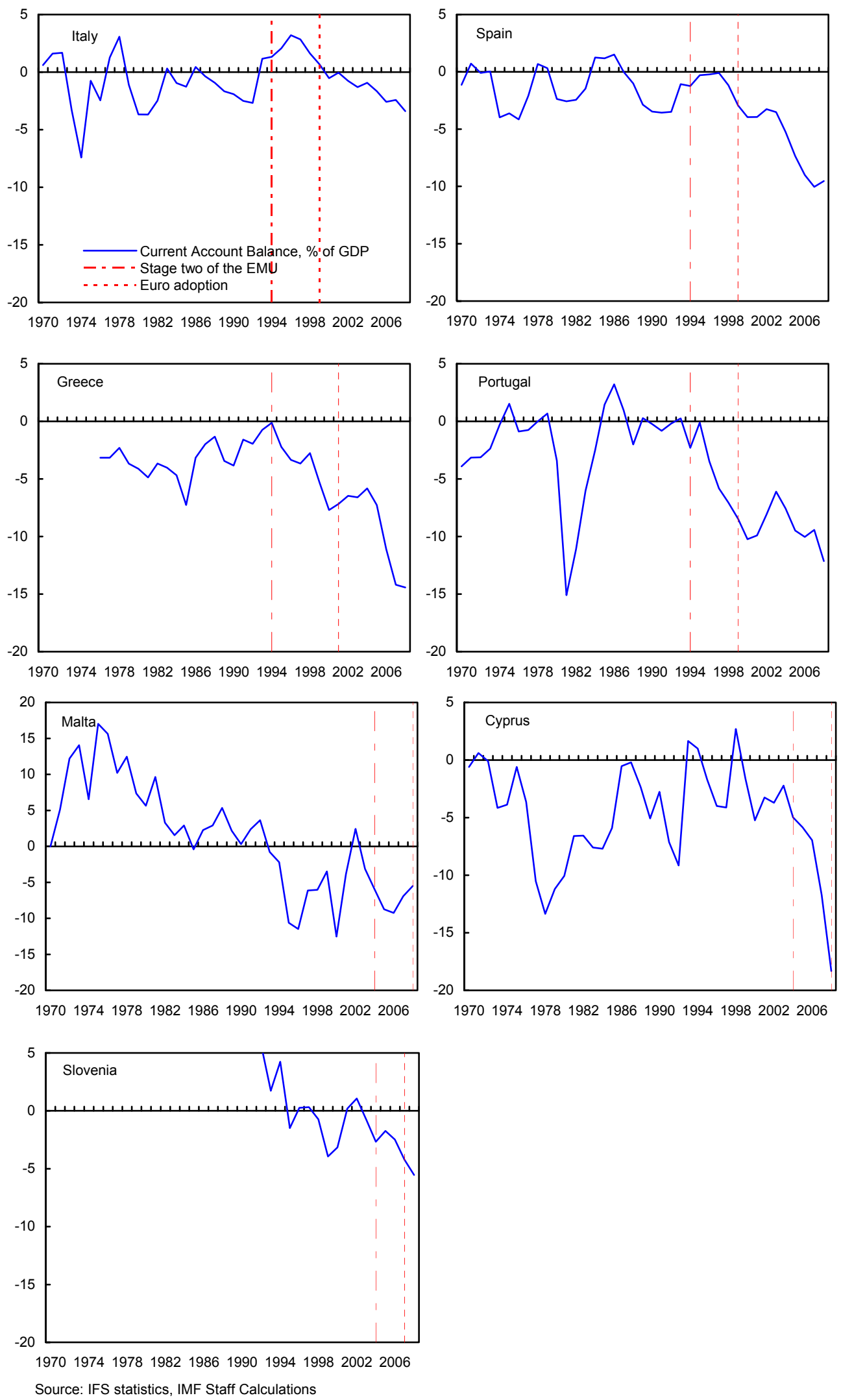
Figure 3. Southern Euro Area: Savings and Investment
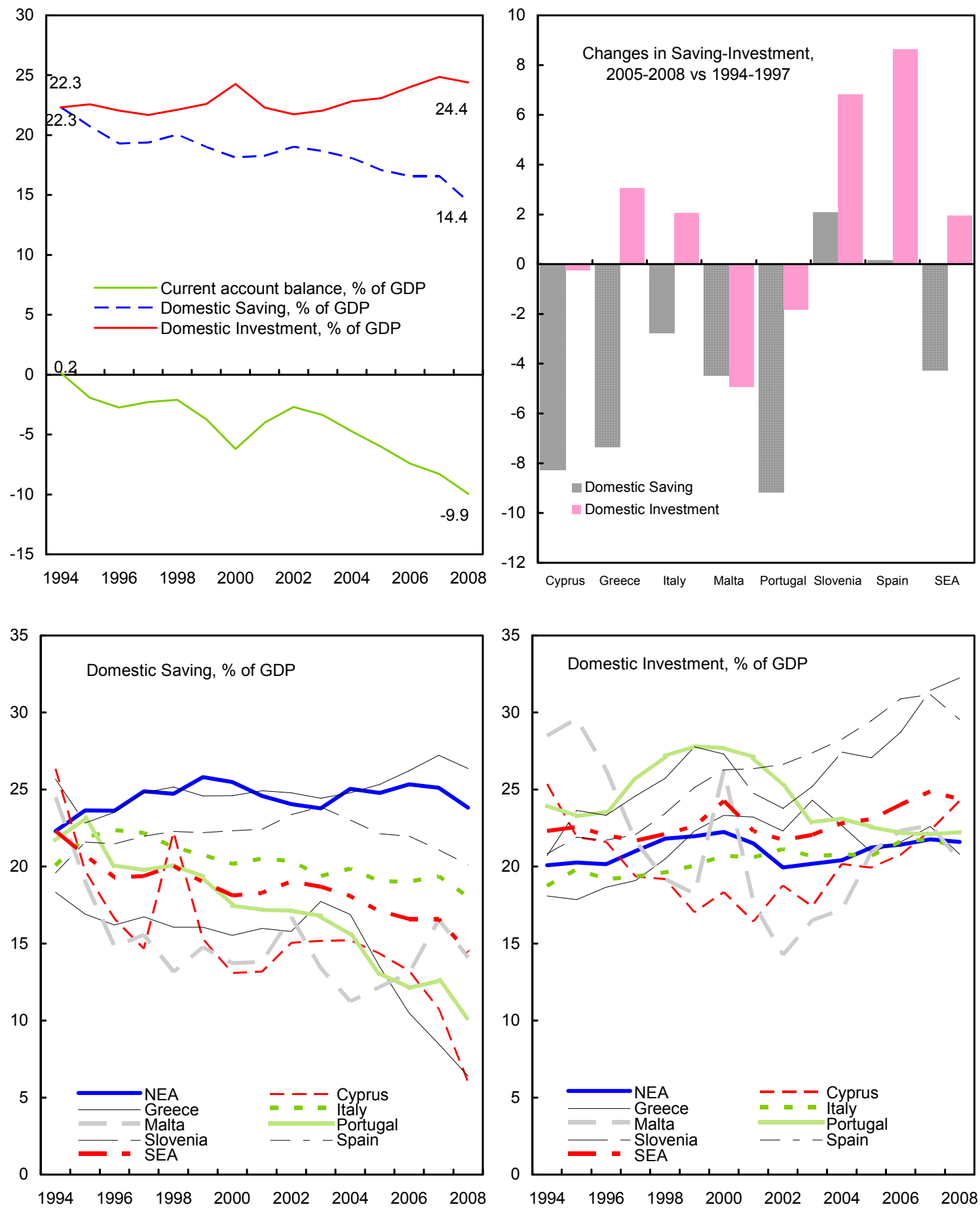

Source: IFS statistics, IMF Staff Calculations 
Figure 4. Southern Euro Area: Private and Public Saving
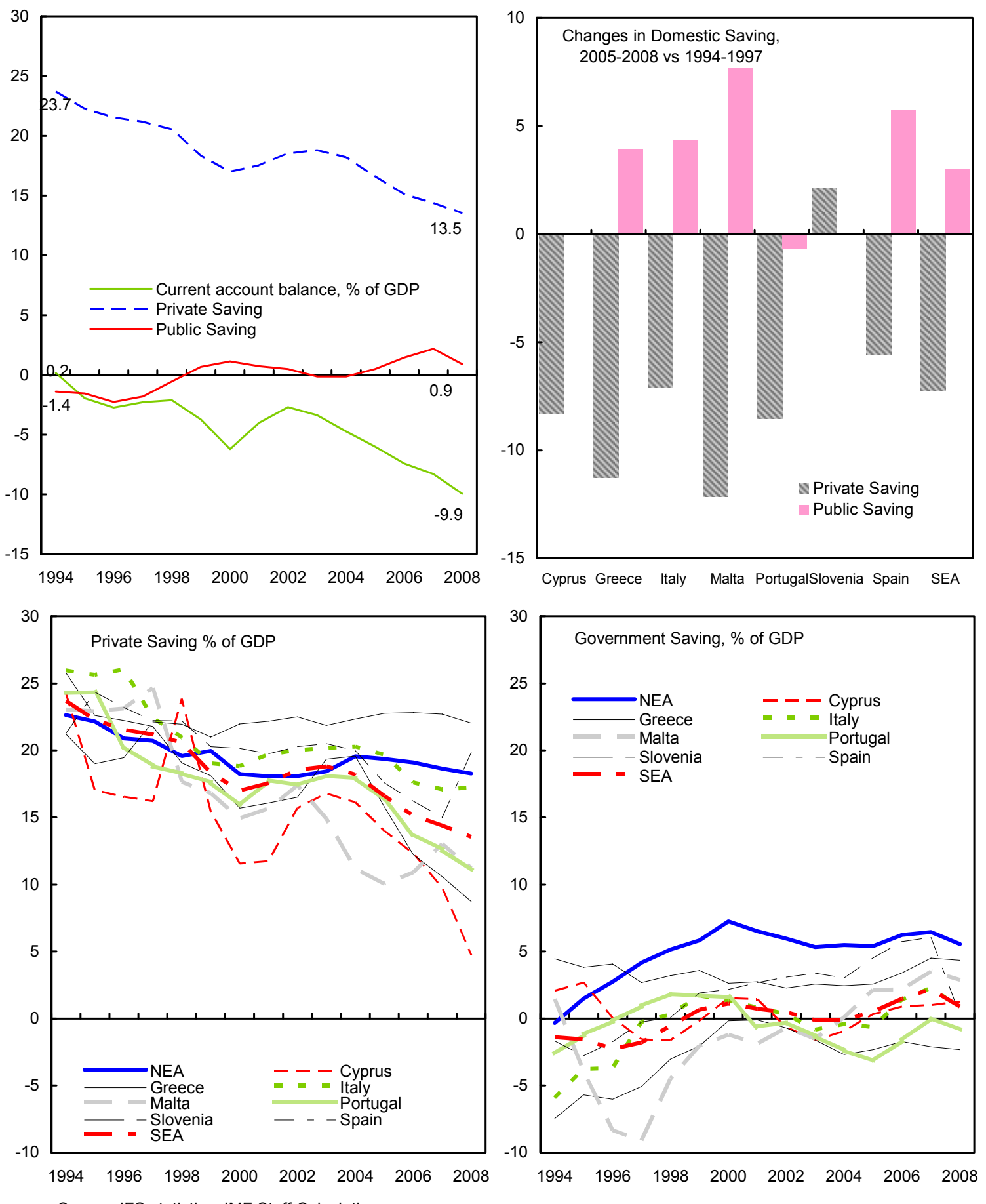

Source: IFS statistics, IMF Staff Calculations 
Figure 5. Southern Euro Area: Private and Public Investment
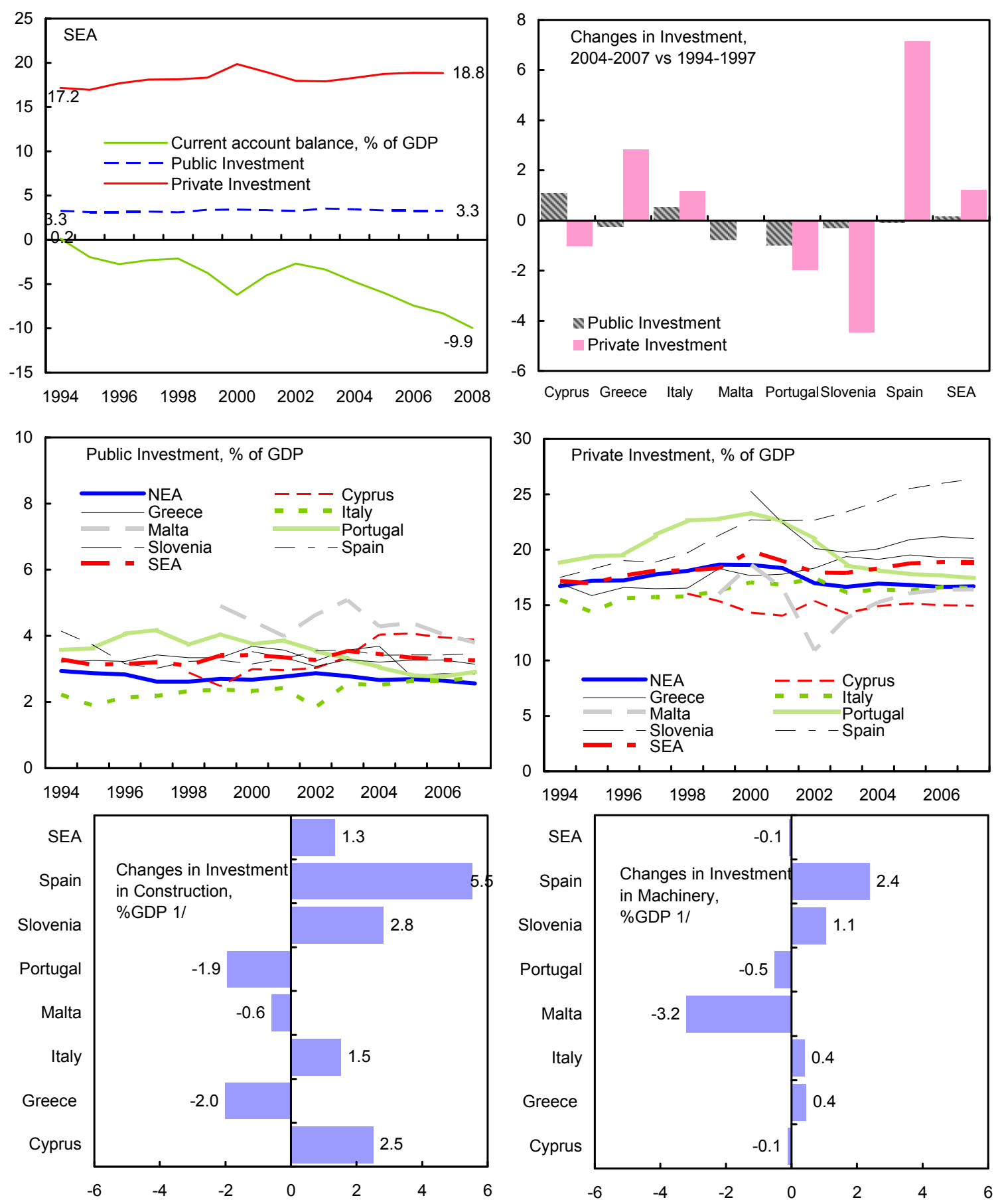

Source: IFS statistics, IMF Staff Calculations

$1 /$ Taken into account the changes in investments from 1995-1998 to 2005-2008, except for Greece which uses the interval 2000-2003 versus $2005-2008$ due to data availability. 
Figure 6. Southern Euro Area: Financing of Current Account Balances (Percent of GDP)
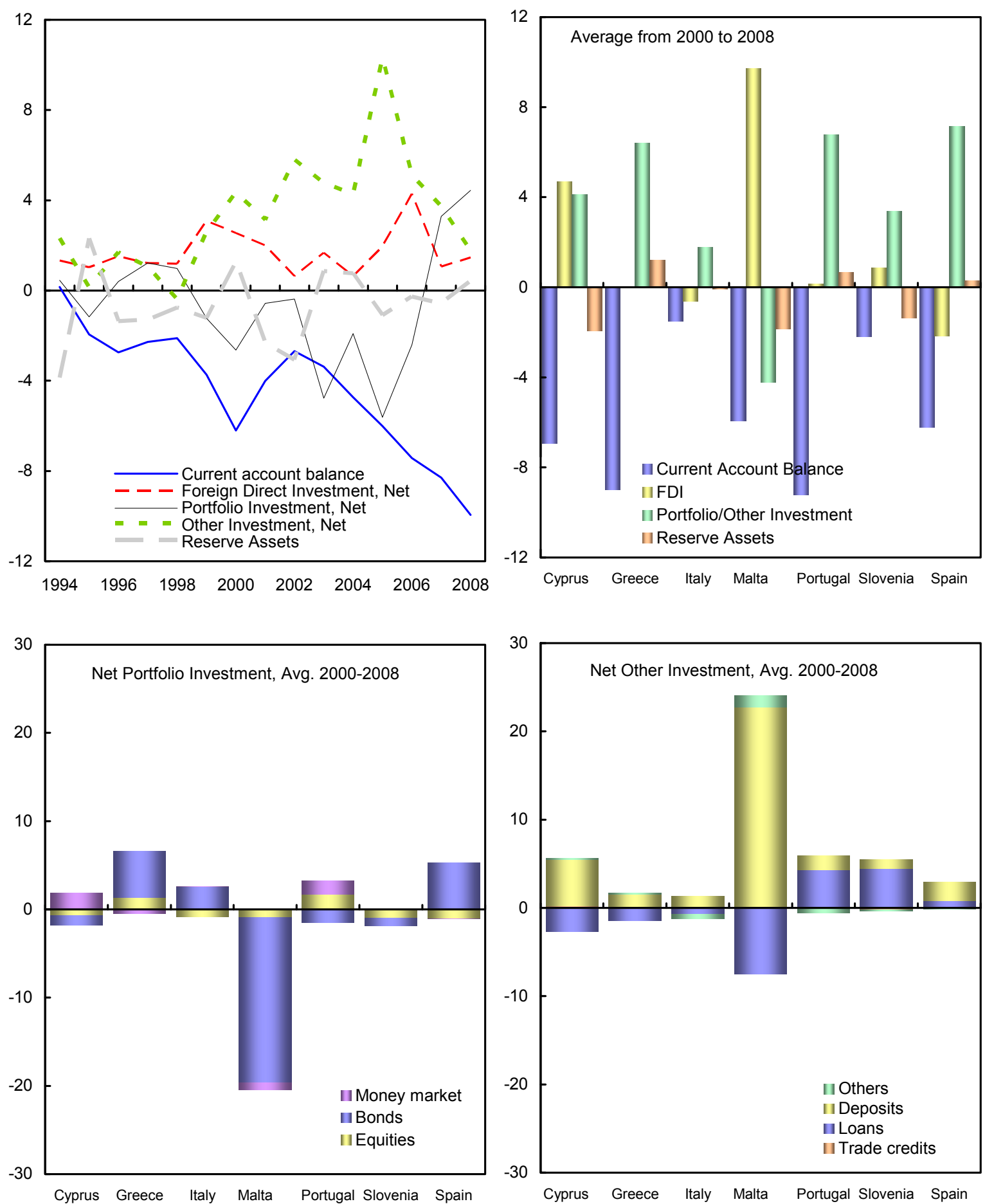

Source: IFS statistics, IMF Staff Calculations 
Figure 7. Euro Area: Components of Current Account Balances
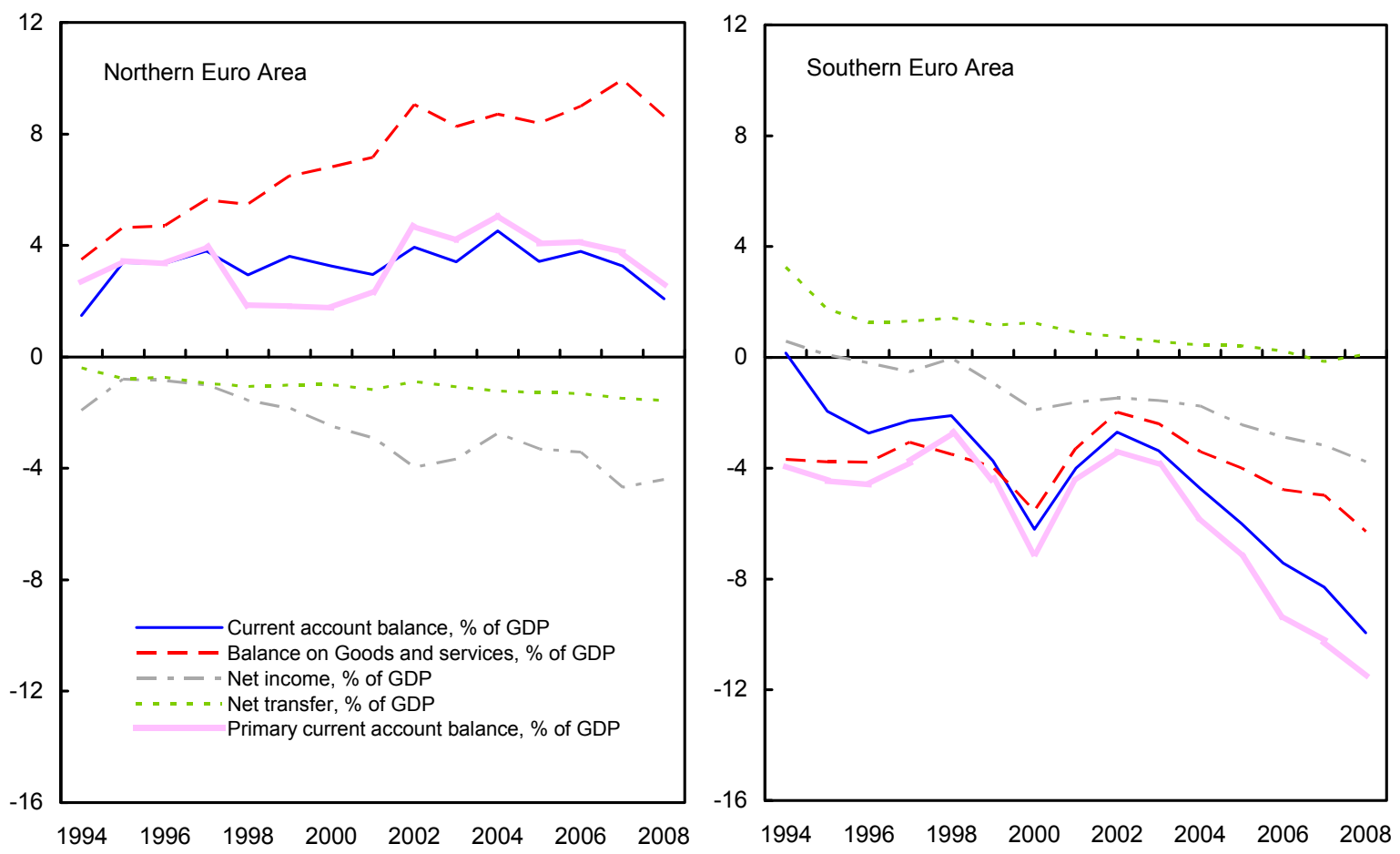

Source: IFS statistics, IMF Staff Calculations

Figure 8. Net International Investment Position

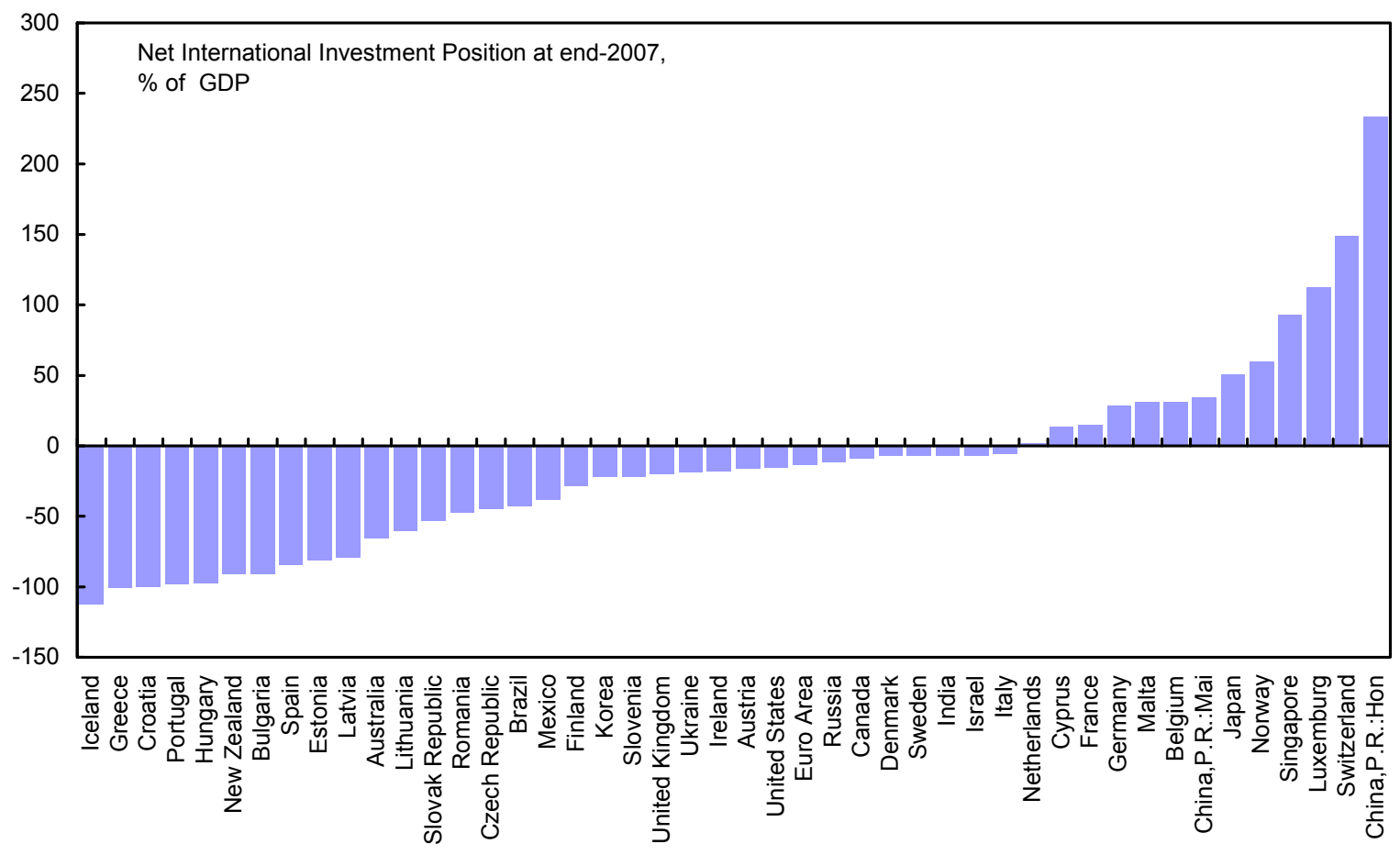

Source: IFS Statistics, IMF Staff Calculations 
Figure 9. Euro Area: EMU and Current Accounts

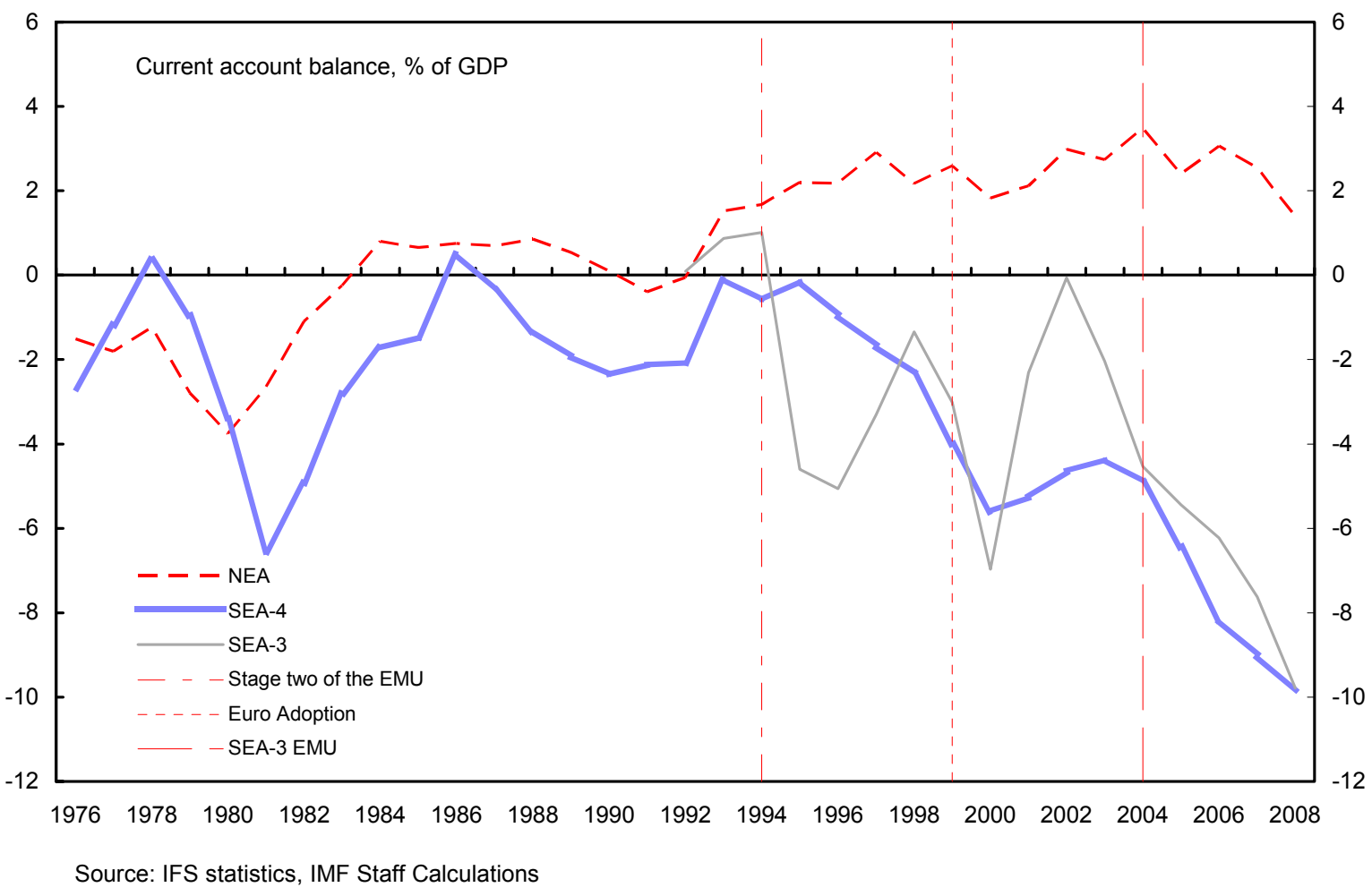


Figure 10. Southern Euro Area: EMU and Financial Liberalization
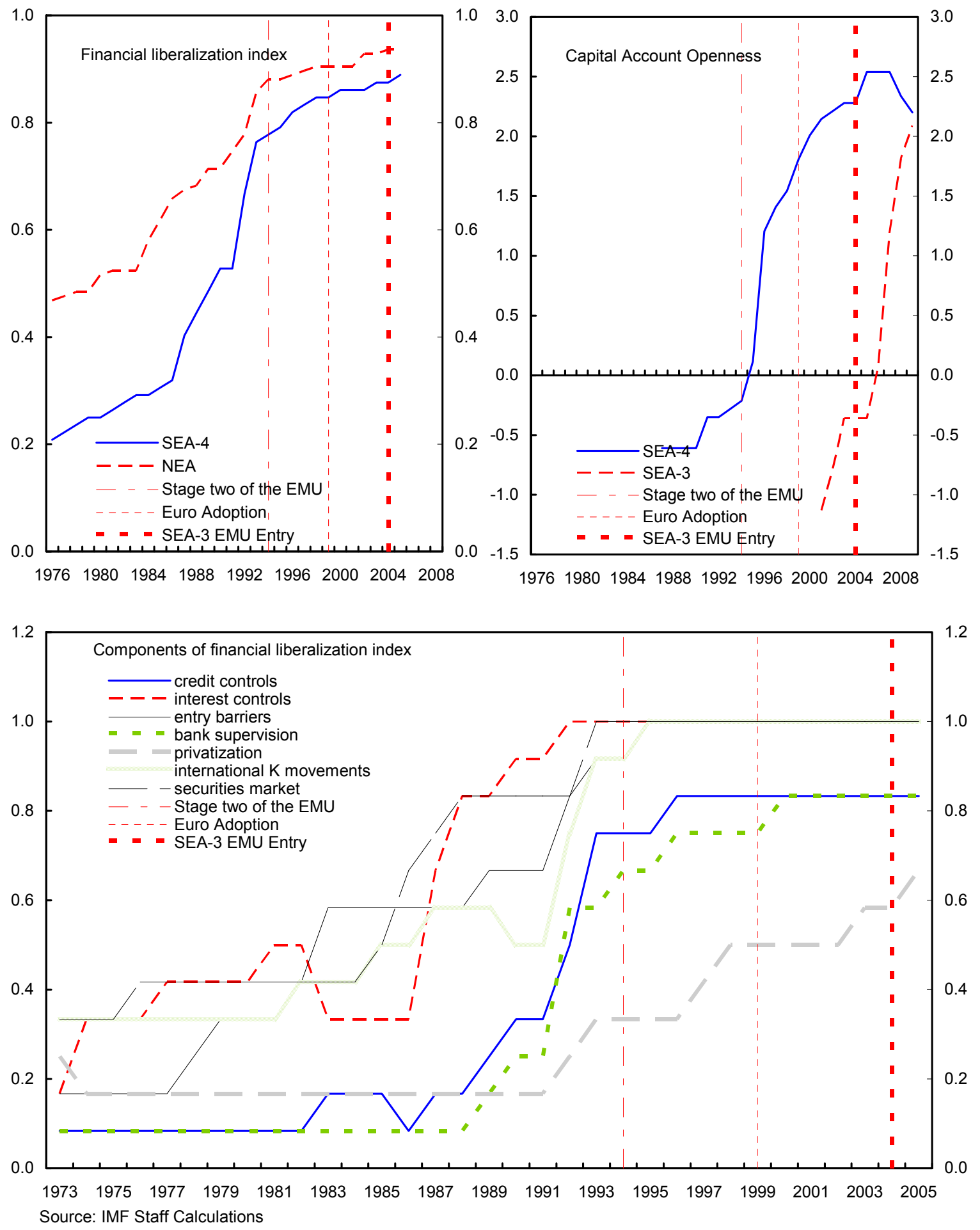
Figure 11. Macroeconomic Policy Developments
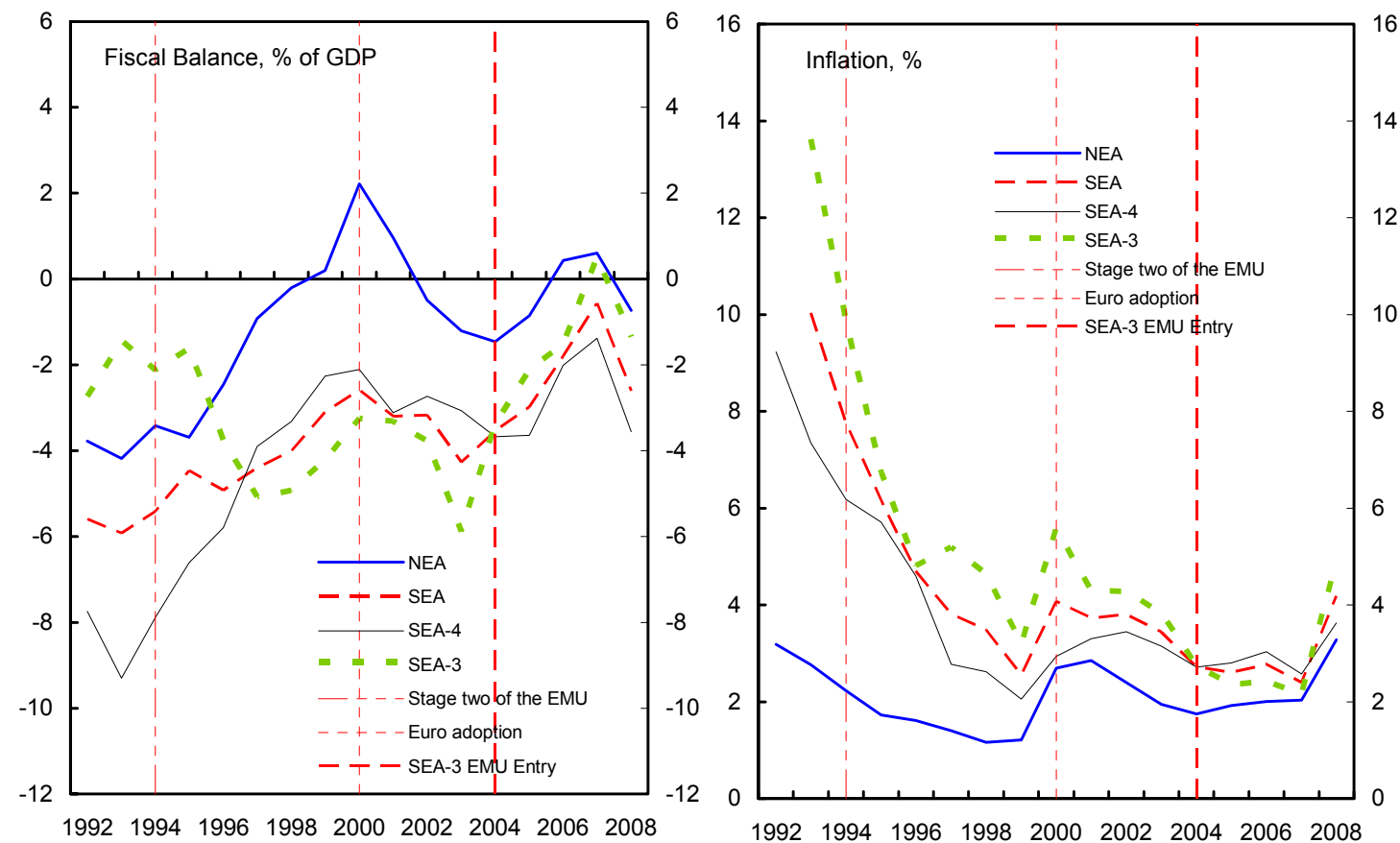

Source: IFS statistics, IMF Staff Calculations

Figure 12. Euro Area: EMU and Interest Rates

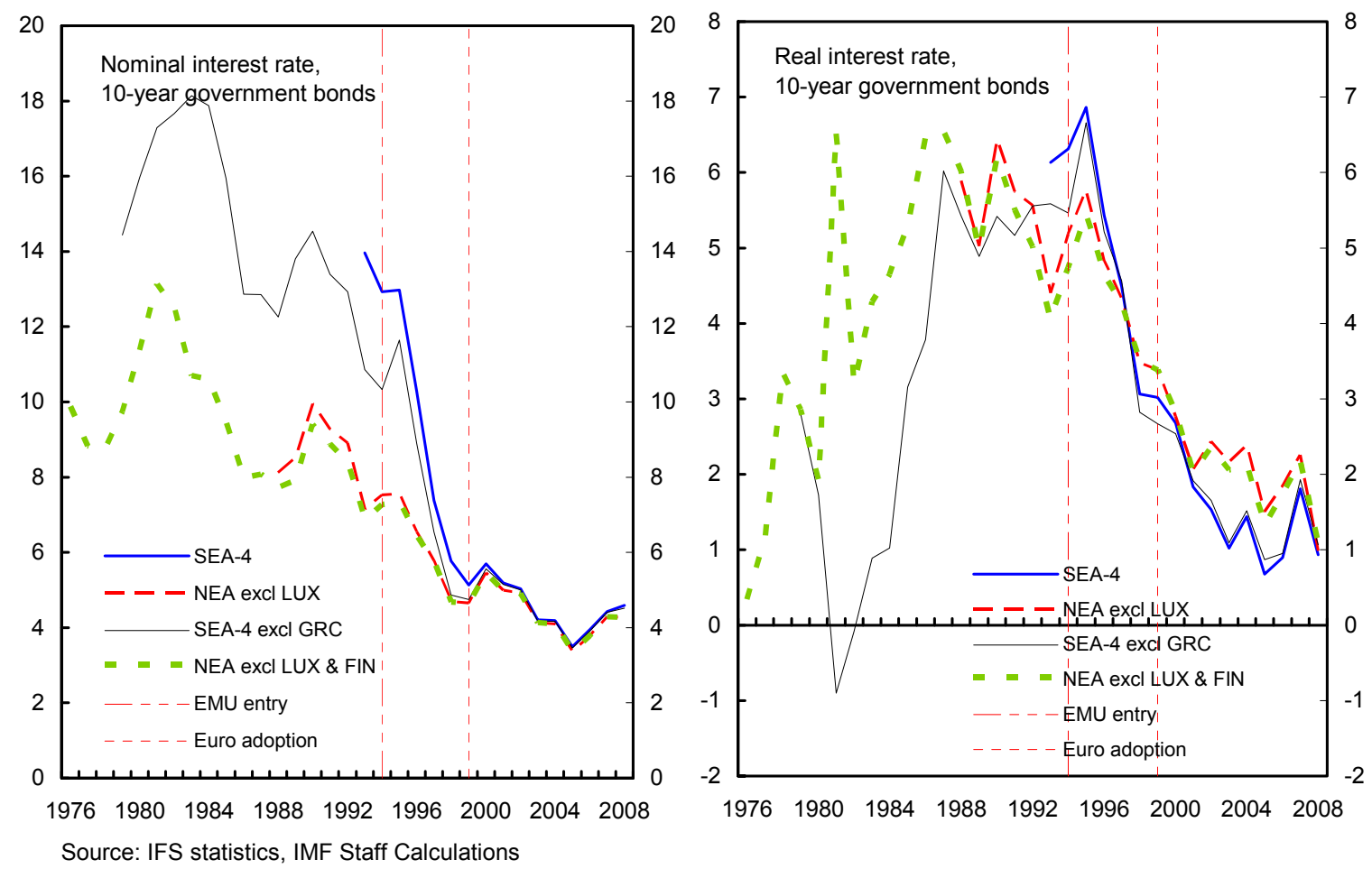


Figure 13. Euro Area: Contributions to Changes in Current Accounts, Savings and Investment Rates, 2005-2008 versus 1989-1992

Current Account

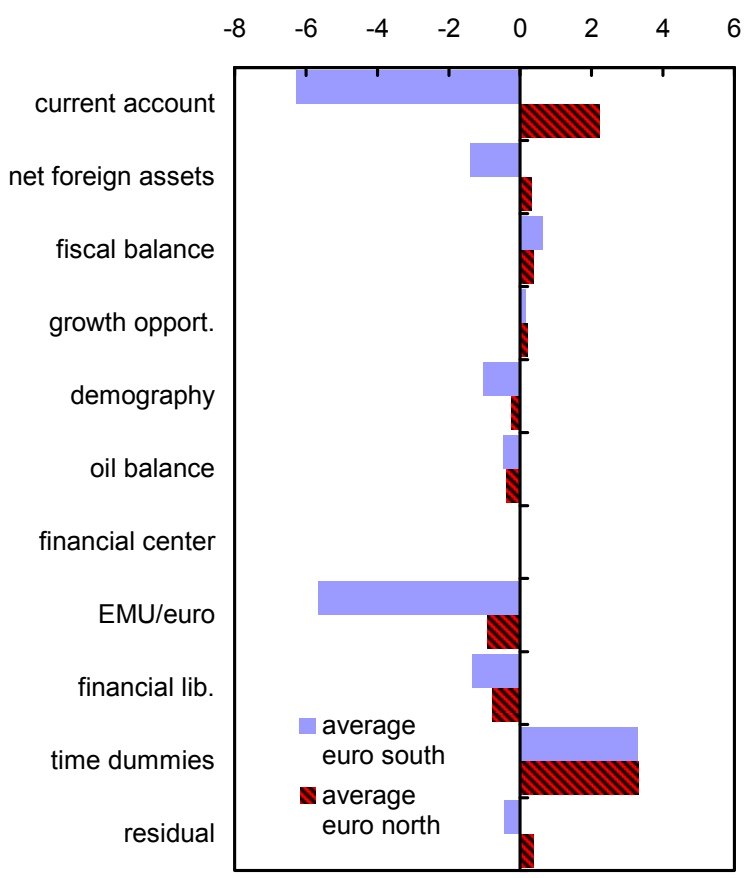

Investment Rate

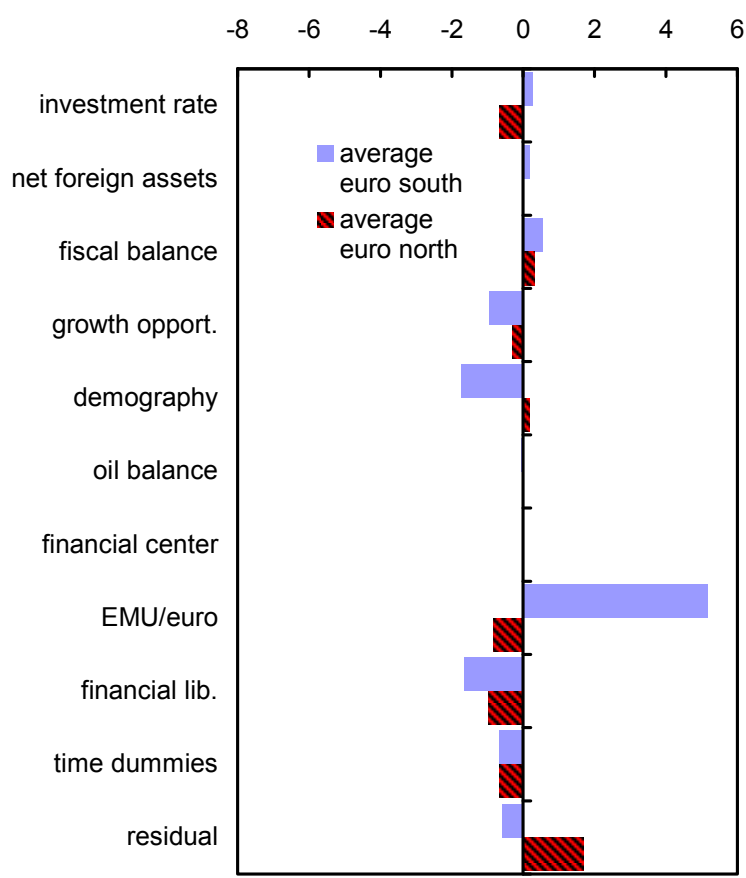

Source: IMF Staff Calculations
Savings Rate

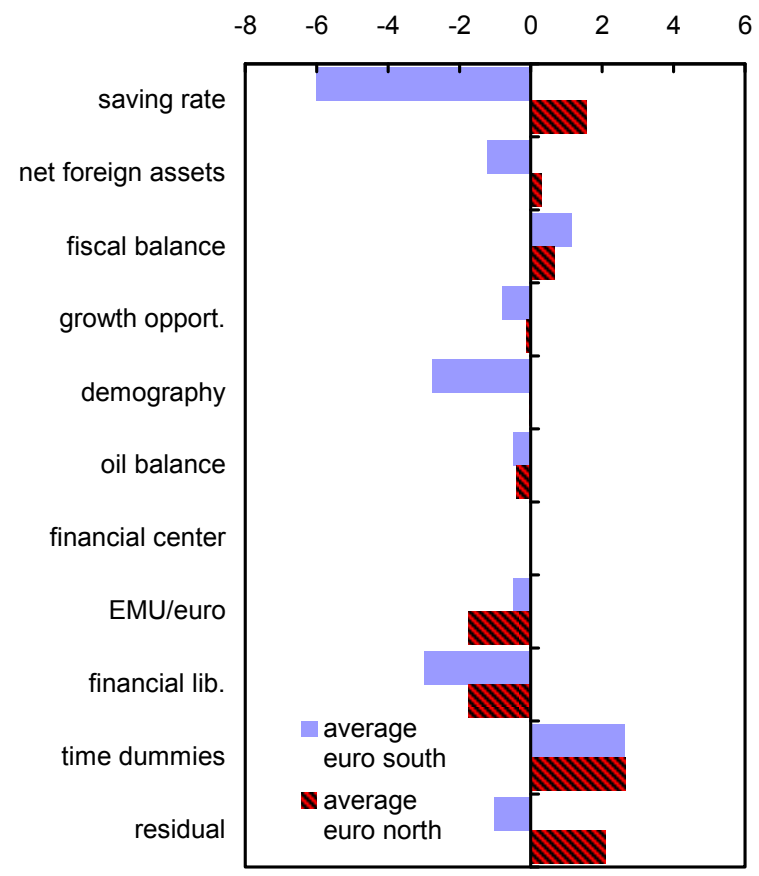

Investment Rate Controlling for Lagged Saving Rate

$\begin{array}{llllllll}-8 & -6 & -4 & -2 & 0 & 2 & 4 & 6\end{array}$

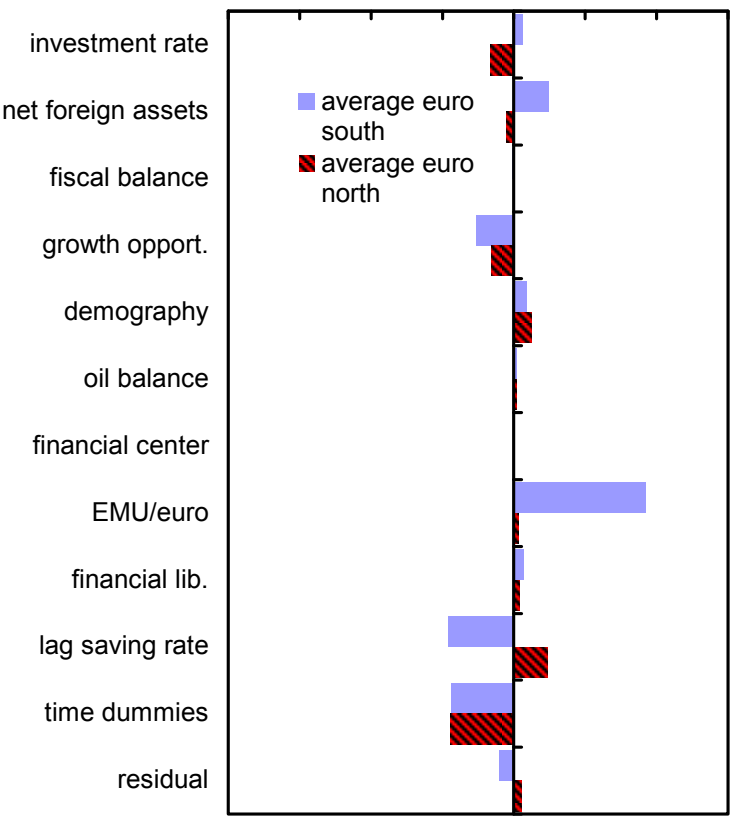


Figure 14. Old Age Dependency Ratio

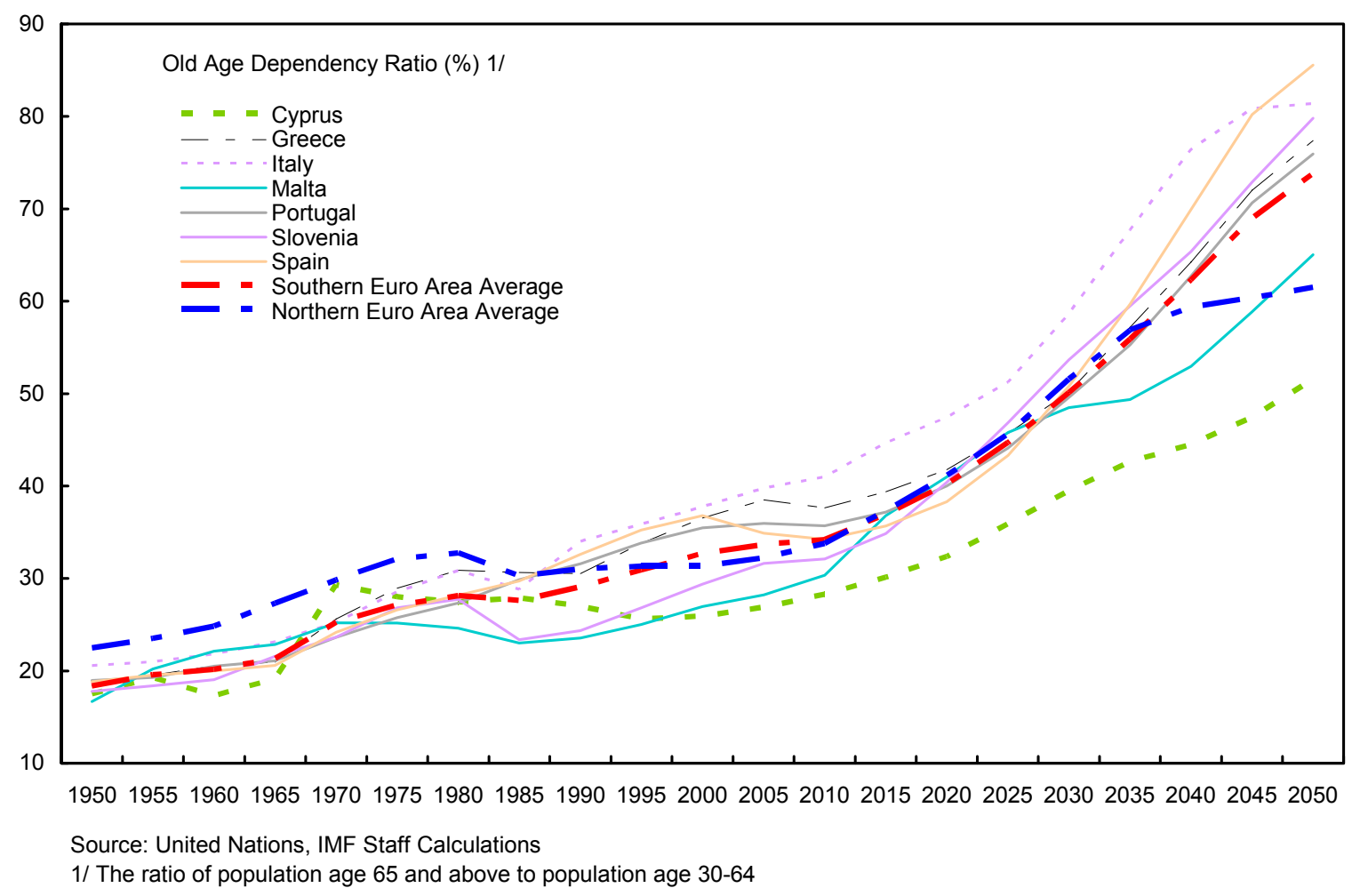


Figure 15. Southern Euro Area: Contributions to Difference in Current Accounts, Savings Rates and Investment Rates from Northern Euro Area, 2005-2008
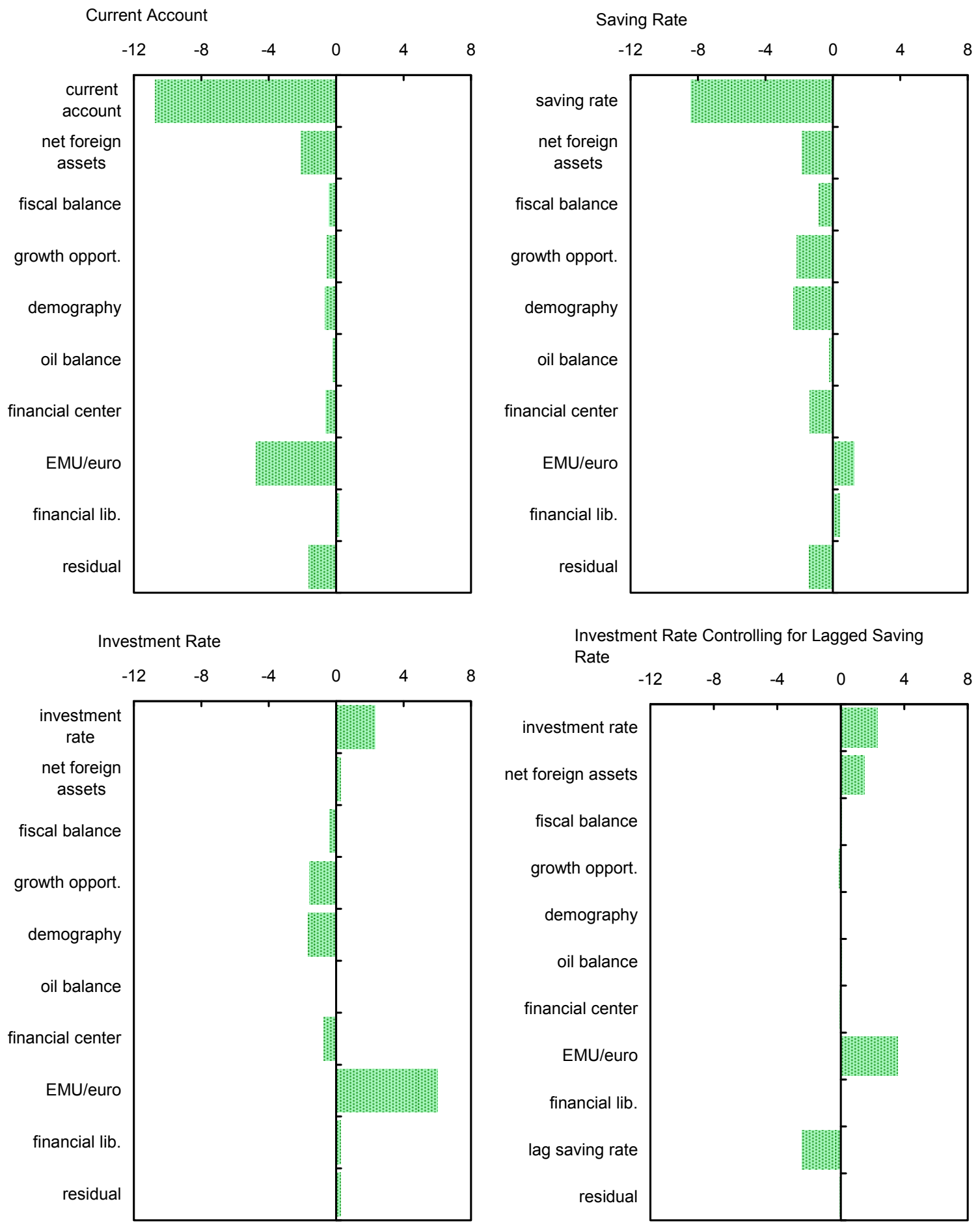

Investment Rate Controlling for Lagged Saving Rate

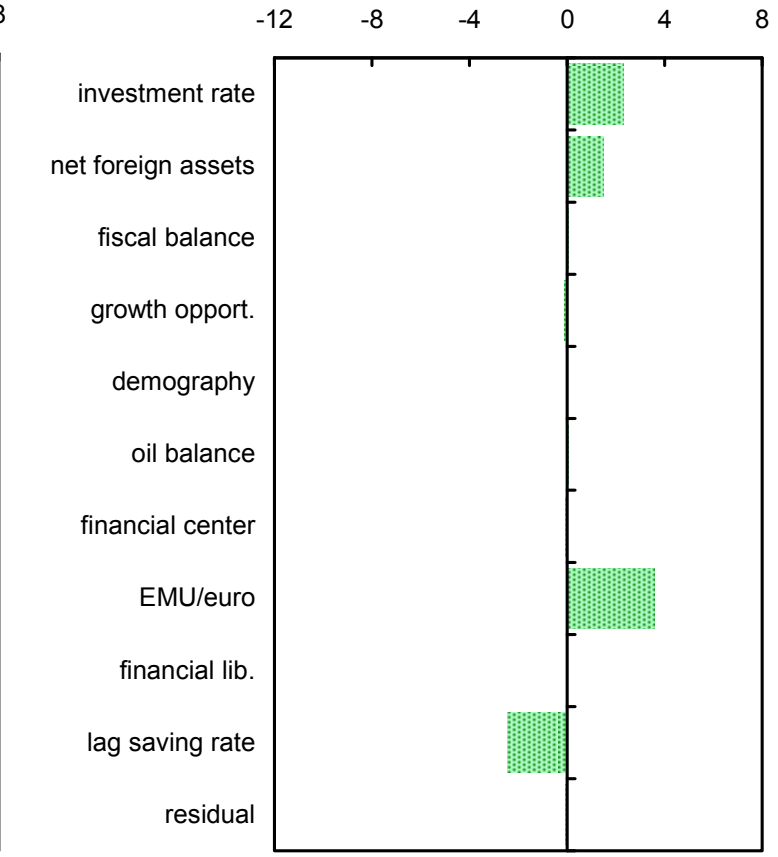

Source: IMF Staff Calculations 
Figure 16. Real Effective Exchange Rate
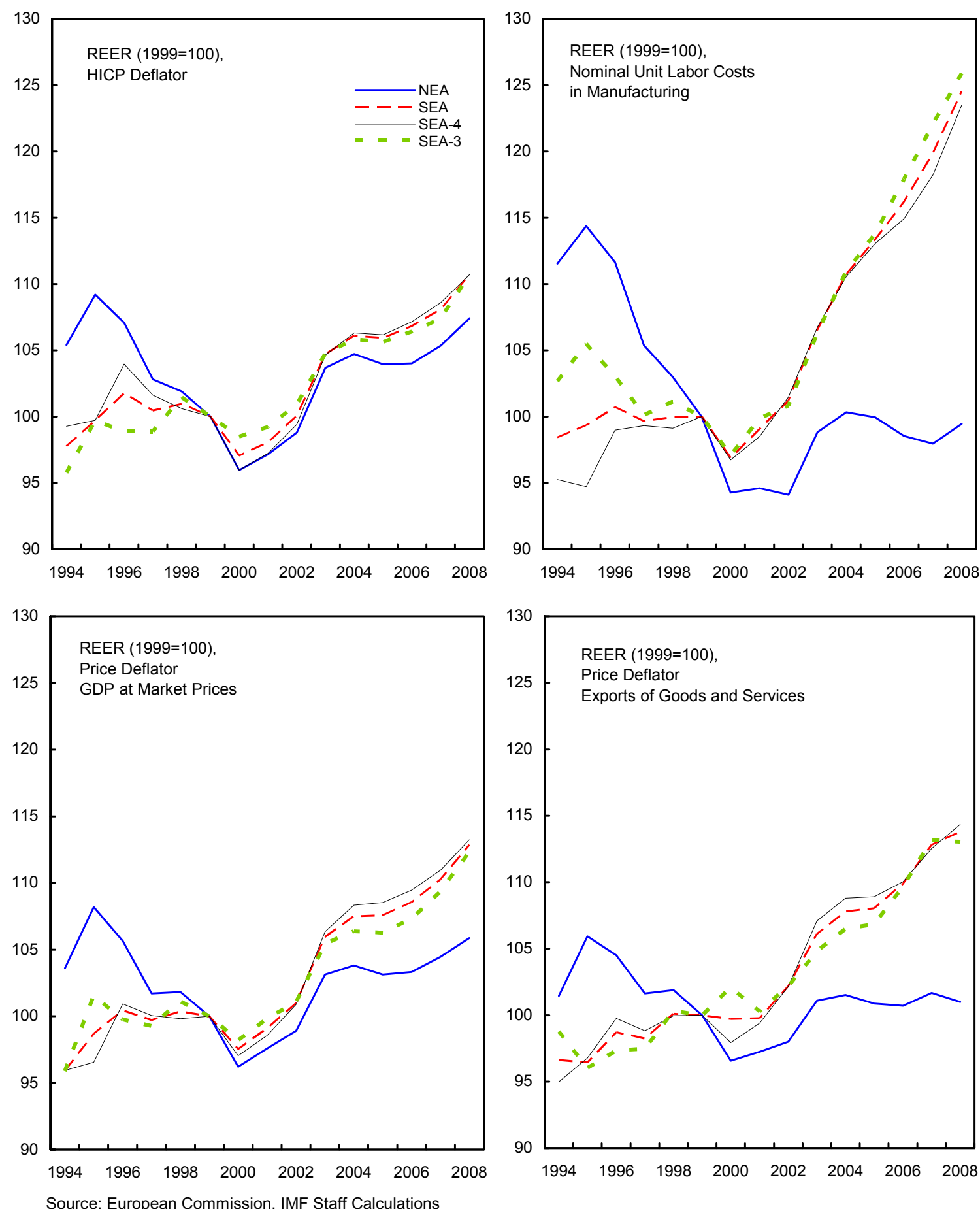
Figure 16 (continued). Real Effective Exchange Rate
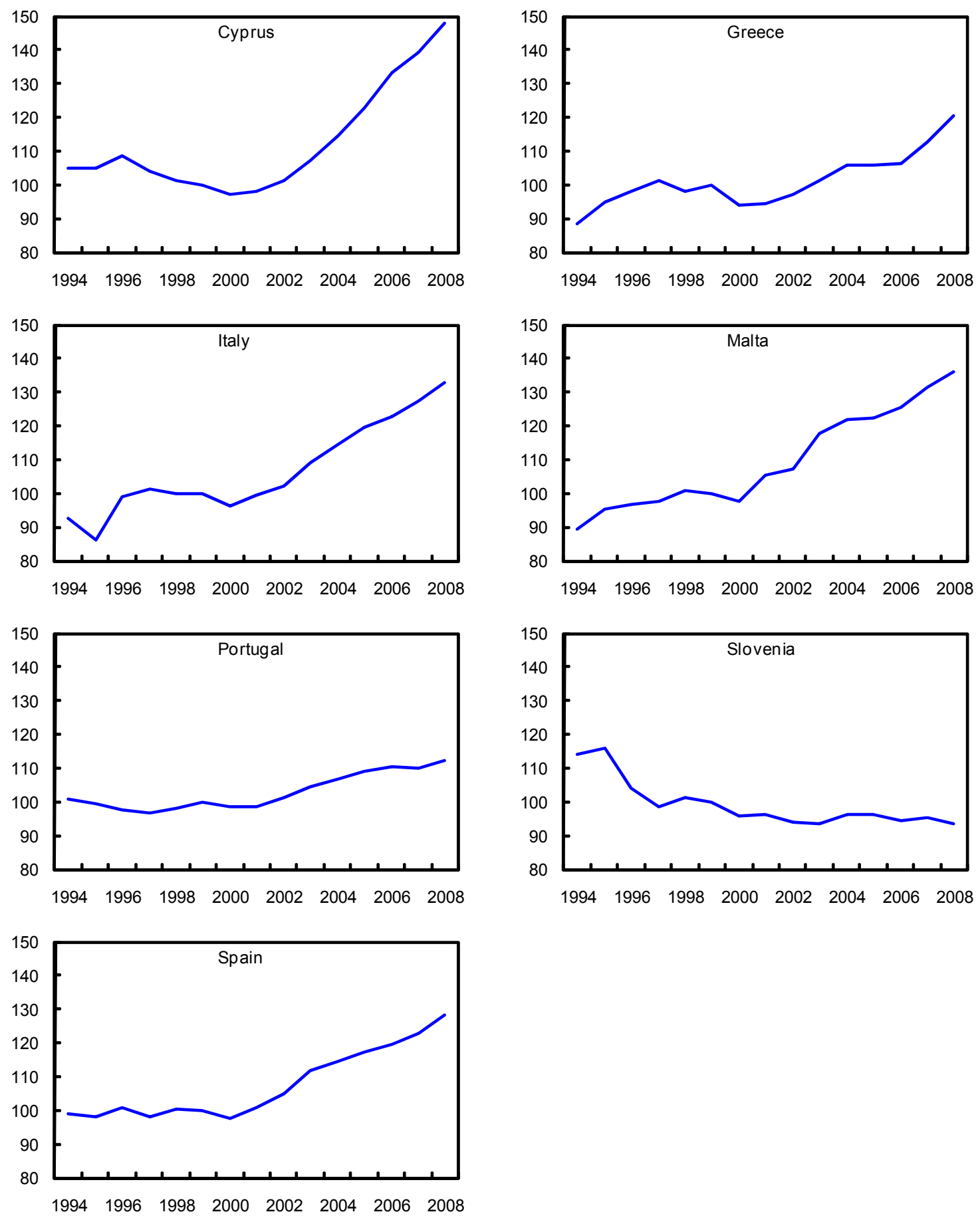

Source: European commission

$1 /$ Real effective exchange rate $(1999=100)$ calculated from nominal unit labor cost in manufacturing sector. 
Figure 17. Euro Area: EMU, Economic Growth, and Output Gaps
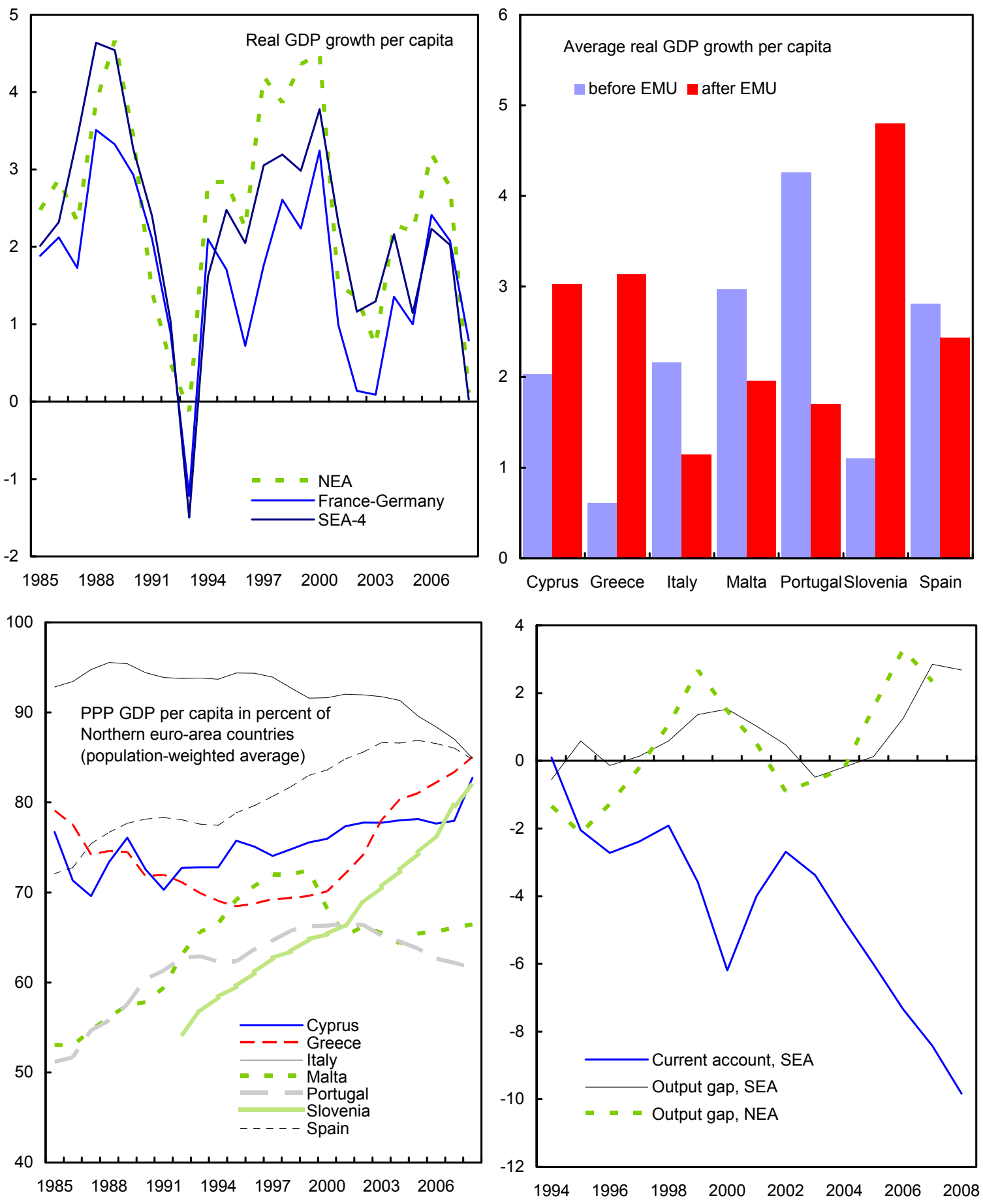

Source: IFS statistics, World Bank WDI, IMF Staff Calculations 
Figure 18. Current Account Norms 1/

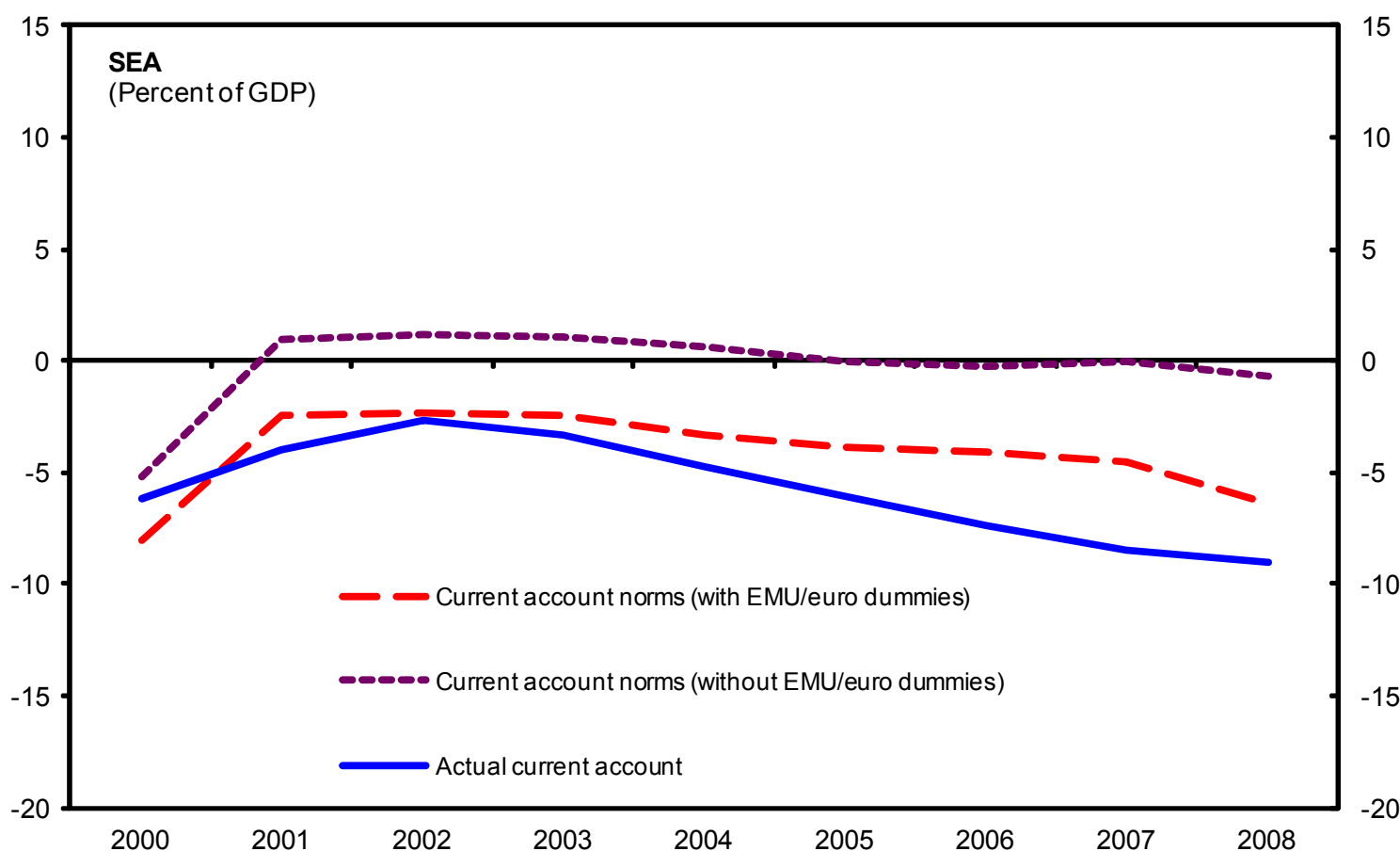

Source: IMF Staff Calculations

1/ Current account norms derive from the benchmark model shown in Table 3. For Cyprus, Malta, and Slovenia, the financial liberalization index is set at Greece's level due to lack of data. However, there is evidence on some subcomponents of the index suggesting that these countries' financial structures are aligned. 
Figure 19. The Unwinding of Imbalances from the Global Crisis
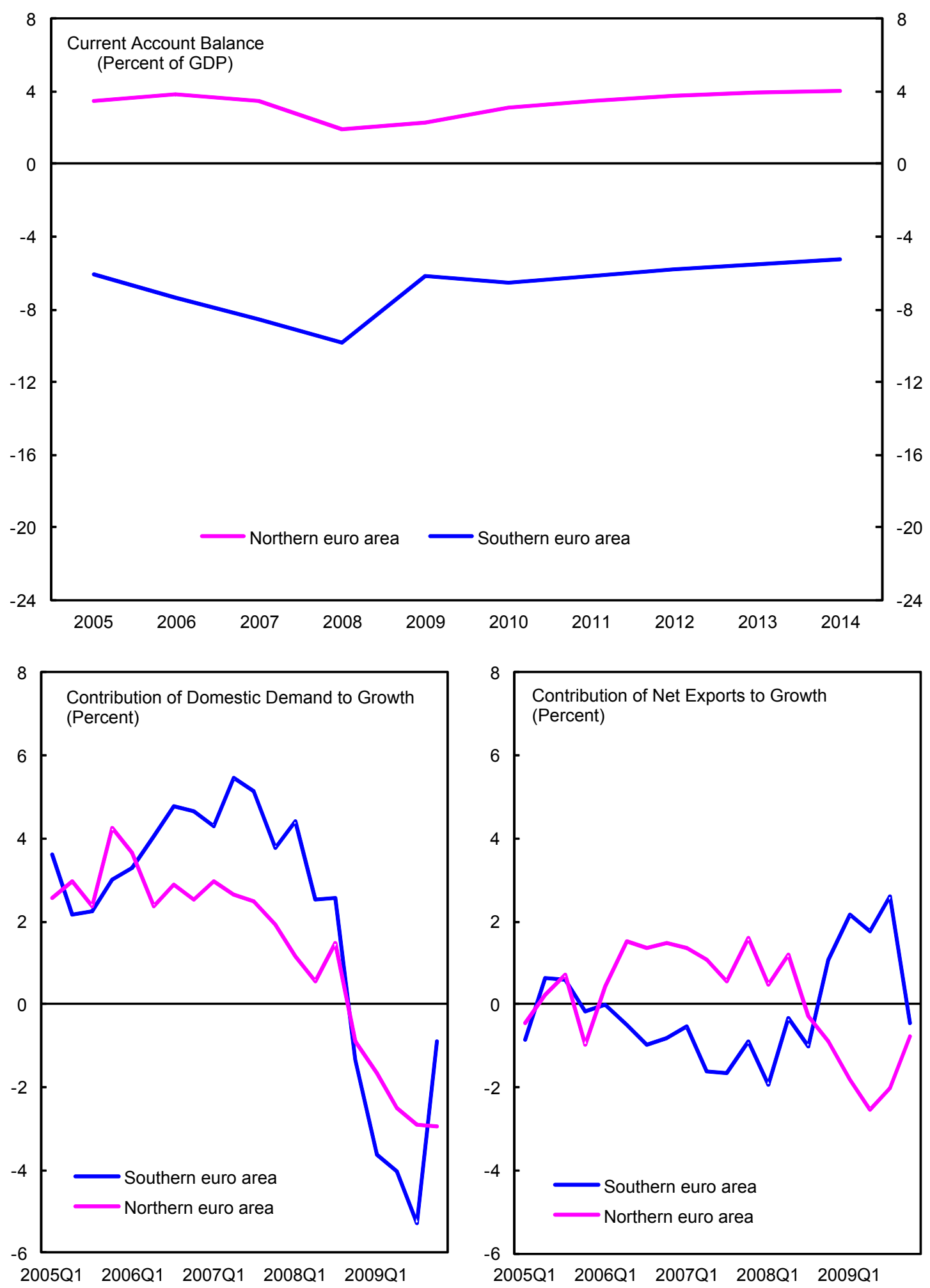

Source: IFS statistics, IMF Staff Calculations; IMF World Economic Outlook 